\title{
A review of persistent organic pollutants: dioxins, furans, and their associated nitrogenated analogues
}

\author{
Samuel K. Kirkok ${ }^{1}$. Joshua K. Kibet ${ }^{1}\left[\right.$ ] Thomas K. Kinyanjui $^{1} \cdot$ Francis I. Okanga $^{1}$
}

Received: 27 April 2020 / Accepted: 17 September 2020 / Published online: 24 September 2020

(c) Springer Nature Switzerland AG 2020

\begin{abstract}
Dioxins and furans are no doubt the most notorious class of organochlorine toxicants in the environmental system whose adverse effects are detrimental to public health with extreme negative economic impacts. Polychlorinated dibenzo$p$-dioxin and dibenzofurans and dioxin-like compounds such as the polychlorinated biphenyls, carbazoles are in the class of persistent organic pollutants-prioritized under the Stockholm convention as the "dirty dozens", besides being listed as group 1 human carcinogens by the International Agency for Research on Cancer. Because of their recalcitrant nature in the environment, bioaccumulation in lipids of cells of animals and their general toxicities, this family of compounds has received increased scientific interest in pollution and toxicology research. Accumulation of these toxicants in lipids of animals, and human exposure has been traced to animal products such as meat, eggs, milk and fish. Combustion events, industrial and municipal waste incineration practices, open fires and some industrial activities especially those dealing with metallurgy are well-established sources of these environmental contaminants. The critical aspects of dioxins, furans and their analogues; notably their sources their mechanistic formation by precursor initiation, de novo pathways, how they manifest their toxicity by activation of aryl hydrocarbon receptor, detoxification of these chemicals from the environment and the analytical methods used to quantify and detect from environmental sample matrices has been explored in this work. This review also provides an in-depth examination of the toxic characteristic behaviour of dioxins and furans, polycyclic aromatic hydrocarbons as well as the emerging nitrogenated analogues of dioxins such as polychlorinated carbazole, and carbazole itself.
\end{abstract}

Keywords Dioxins $\cdot$ Furans $\cdot$ Toxicity $\cdot$ Mechanism $\cdot$ Polychlorinated carbazole $\cdot$ Contaminants

\section{Introduction}

\subsection{Background}

Persistent organic pollutants (POPs) are conventionally referred to as hazardous organic contaminants considered resistant to metabolic, chemical, microbial and photolytic degradation procedures [46]. These recalcitrant pollutants are a historical problem in the environment; soil, water and air because of their long half-lives which range from decades to centuries [125]. Historically, polychlorinated dioxins and furans can be traced to the Vietnam War of 1957-1971 in which a supposedly precursor of dioxin 'orange agent-herbicide' was used during the war with the intention to wipe out food crops, and probably win the war through starvation of the Vietnamese soldiers [39]. There have been other unintentional cases that led to dioxin formation such as the chick edema disease of 1957 and the North Eastern pharmaceutical and chemical company in Missouri which accidentally generated dioxins in the 1970s [39]. Conventionally, dioxins and furans mainly originate from chemical-combustion events, forest fires,

Joshua K. Kibet, jkibet@egerton.ac.ke; Samuel K. Kirkok, kirkokkipyegon@gmail.com; Thomas K. Kinyanjui, tkinyanjui@egerton.ac.ke; Francis I. Okanga, fokanga@egerton.ac.ke| 'Department of Chemistry, Egerton University, P.O Box 536, 20115 Egerton, Kenya. 
municipal waste incineration and metallurgy in addition to natural events including volcanic eruptions and possible lightning disasters, and are therefore inadvertently released to the environment as by-products of human and natural activities [95]. Their pollution effects impact negatively on the environment, health and economy, and are well-known carcinogens as well as mutagens [46]. Due to their persistence in the natural environment, their toxicity and bioaccumulation in biota, they pose an enormous risk to humans, animals and the general ecological systems [46]. They bio-accumulate in human fatty tissues and have therefore been widely associated with developmental, reproductive and hormonal adverse health effects in humans [95].

In the last few decades, the detection of halogenated heterocyclic chemicals and their associated nitrogenated heterocylic analogues such as carbazoles as well as polyhalogenated carbazoles (PHCZs) have received increased mounting attention in environmental sample matrices from various ecosystems; water, indoor air, and foods [101]. This underscores what scientific findings have stated as notorious 'super poisons' distributed in the environment. The toxicity of halogenated heterocyclic compounds for example halogenated carbazoles to biota and humans have drawn a lot of interest [32]. It is important to note that halogenated carbazoles are structurally similar to polychlorinated dibenzo- $p$-dioxin and halogenated dibenzofurans; therefore they are believed to be extremely toxic because of their dioxin-like characteristic behaviour attributed to similarity in their molecular conformations [32]. Polyhalogenated carbazoles (PHCs) which has been established to be non-degradable in the soil [73] display toxicities similar to those of dioxins and furans and are precursors for carcinogenesis, developmental defects and lowered immunity in animals [92].

Heterocyclic compounds of the polycyclic heteroaromatic group are well known environmental pollutants that are discriminately abundant in the environment and whose source and environmental pathways are known to be mainly anthropogenic as well as from combustion activities $[73,86]$. Nitrogenated aromatic heterocyclic compounds generally are components of crude oil and include carbazole and dibenzopyrroles among other heterocycles of toxicological significance [32]. These compounds are remarkable environmental pollutants because they emit oxides of nitrogen (NOx) which have the ability to deplete the ozone layer in addition to causing acid rains [56]. In oil refinery practices, nitrogen containing heterocyclic compounds is credited for reducing the efficiency of catalysts used in the thermal cracking process by poisoning action thus causing economic loses and possible hazard capabilities $[19,64]$. Accordingly, these chemicals compromise the quality of the oil products, resulting to serious economic and environmental impacts $[49,98]$. The emerging nitrogen-containing heterocyclic polycyclic aromatic compounds (N-PACs) which individually or in a mixture with PAH pollute soils, air and water $[5,63]$ display similar toxicological action as polyaromatic hydrocarbons (PAHs) [2]. N-PACs are suggested to form from the pyrolysis of lignocellulosic materials, sewage degradation, open fires, and natural events such as lightning [128] although some of these chemicals have been isolated from sewage sludge and fly ash [27].

Other environmental pollutants which are viewed as by-products of combustion and industrial activities, and are categorized as neither dioxins, dioxin-like nor furans include aliphatic and aromatic hydrocarbons, chlorine containing aromatics, some pesticides and herbicides applied in agricultural practices [97], nonetheless, dioxins and furan including their associated nitrogenated analogues remain a novel group of notorious environmental toxins. Remarkably, dioxins and dioxin-like compounds may be polychlorinated aromatic chemicals which are well established carcinogens and mutagens widely reported to cause adverse damage to biological tissues which ultimately result in oxidative stress, cancer, and cardio pulmonary diseases of grave concern [62]. Synthesis of haloaromatic chemicals and incineration of chlorine containing organic materials are other important sources of dioxins [97]. Moreover, thermochemical processes yield PAHs [127] and oxy-PAHs [36] which are well known precursors for the synthesis of dioxins, dibenzofurans, and their attendant analogues of the nitrogenated type [135].

Because of the apparent toxicity of dioxins, the health problems they pose to humans, wildlife and marine life as a result of their bioaccumulation characteristics, efforts by many researchers has been directed towards elimination and degradation of these chemicals in polluted environmental and biological systems [84]. The detoxification and degradation processes that have been widely accepted to free the environment from these toxins comprise photodegradation, thermal processes, dechlorination methods aided by metal catalysts, chemical interventions and the utilization of dioxin inhibitors using nitrogen and sulphur compounds in contaminated waste [61]. Nonetheless, due to the drawbacks of these physico-chemical processes, new novel methods have been applied; particularly the use of biological interventions such as the use of microbes to remove toxic and recalcitrant compounds from the environment [44] —this approach has been proven to be economically viable and effective in the reduction of lethal environmental pollutants of the polychlorinated dioxin type [9]. Microorganisms for instance bacteria degrade toxic pollutants such as dioxins to harmless metabolites and intermediates such as phenoxyphenol and possibly methane, $\mathrm{CO}_{2}$, and water, although chlorinated volatiles 
such as $\mathrm{HCl}$ cannot be ruled out [44]. The new emerging environmental pollutants classified as polyhalogenated carbazoles (PHCZs) are increasingly become ubiquitous in the environment and their remarkable similarities in chemical structure and toxicity characteristics with the wellknown halogenated dioxins and furans have caused grave concern among public health authorities [32]. Because of the toxic nature of heterocyclic nitrogenated compounds classified as polyhalogenated carbazoles (PHCZs), dioxins and dioxin-like compounds, there has been an exponential rise in research in this area with a view to understanding the various mechanistic transformations that result to their formation. Of important interest are the various thermochemical or combustion channels that precipitate their formation from biomass materials, forest fires or industrial wastes practices. Figure 1 gives examples of the most common congeners of chlorinated dioxins, furans and polychlorinated carbazole considered detrimental to human health. The structures were modelled using Gaussian'09 computational suite of programs.

Dioxins and furans are categorized into three groups; polychlorinated dibenzo- $\rho$-dioxins (PCDDs), polychlorinated dibenzofurans (PCDFs) and dioxin-like polychlorinated biphenyls (dl-PCBs) (cf. Figure 1). They generally comprise 75 polychlorodibenzo- $p$-dioxins (PCDDs) including the most potent 2,3,7,8-tetrachlorodibenzo-p-dioxin, TCDD, and 135 polychlorinated dibenzofurans (PCDFs), which are structurally similar but only differ in the numbering and position of attachment of the chlorine atom in the dioxin-furan rings $[20,57]$. Other polycyclic aromatic compounds which are equally considered dioxin-like include other congeners of the PCDDs, biphenyls PCBs, diphenylethers, and naphthalenes some of which have toxicities comparable to the most toxic polychlorinated dioxin, TCDD. Some researchers have also argued that chloro- and bromo versions of these compounds constitute dioxin-like analogues [15, 33, 112].

\section{The major sources of dioxin and dioxin-like compounds}

Dioxins, furans and their chemically related analogues are released into the environment through natural sources such as volcanic eruptions and anthropogenic sources including municipal waste incineration, tobacco smoke,

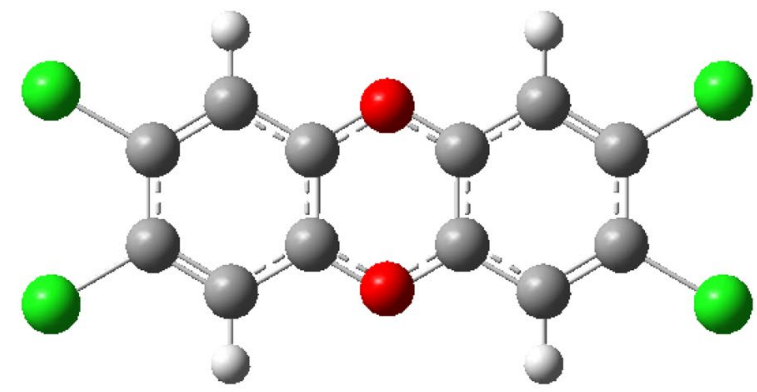

2,3,7,8-tetrachlorodibenzo-p-dioxin

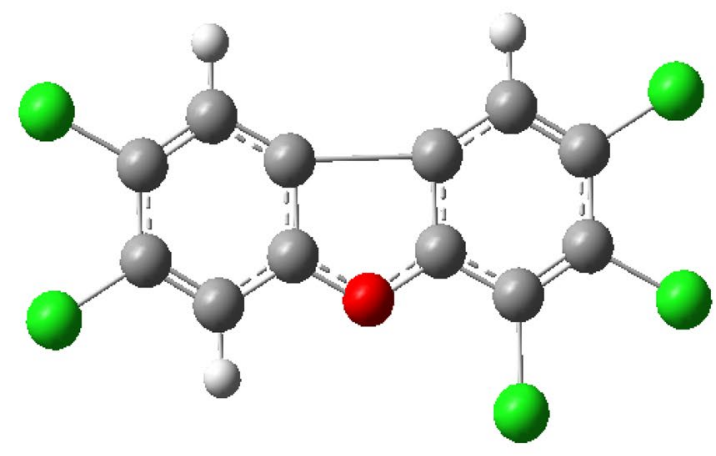

2,3,4,7,8-pentachlorodibenzofuran

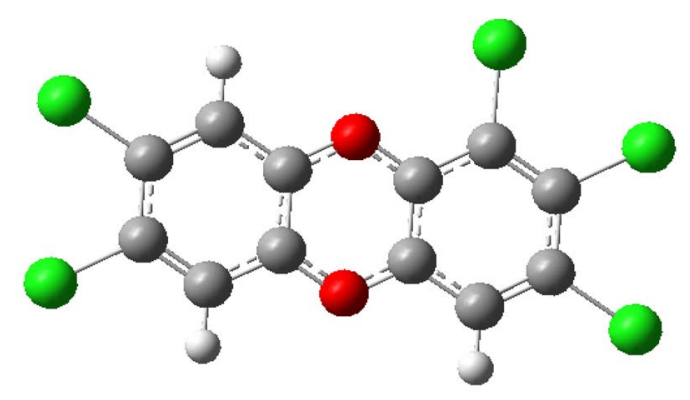

2,3,4,7,8-pentachlorodibenzo-p-dioxin

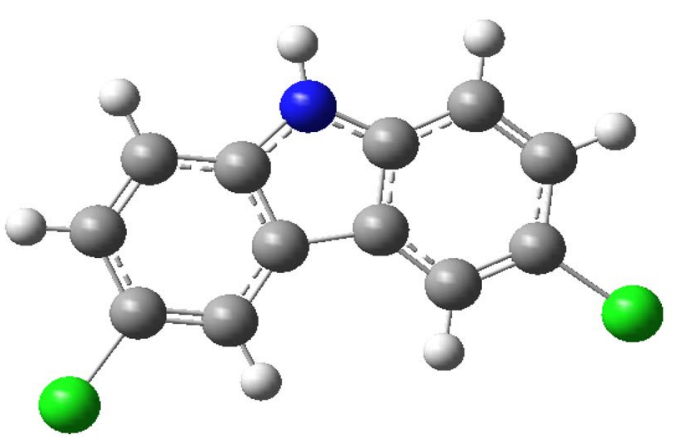

2,8-dichlorocarbazole

Fig. 1 Modelled structures of some selected polychlorinated dibenzo-p-dioxins (PCDDs), polychlorinated dibenzofuran (PCDF) and polychlorinated carbazole. The green atoms represent chlorine while the blue and red atoms are nitrogen and oxygen, respectively 
fly ash and industrial activities (Fig. 2) [9]. Presently, the sources of dioxins differ from the origins proposed some four decades ago because of the strict regulations imposed by government authorities - sources from industrial activities in particular have drastically diminished because of absolute adherence by states to the established regulations aimed at minimizing emission of these human and environmental poisons [129]. It is also well reported in literature that the industrial or small scale synthesis of certain compounds such as chlorophenol based fungicides, polycyclic biphenyls (PCBs) and some herbicides generate PCDD/Fs as by-products [46].

Volcanic eruptions and forest fires also constitute the notorious non-anthropogenic sources of dioxins $[75,90]$. Other sources that are associated with human activities for example burning include; pyrolysis of biomass materials and synthesis of some compounds which release dioxins to the natural environment as toxic by-products $[42,103]$. Moreover, some additives used during the synthesis of these organic substances in turn introduce chlorinated materials into the combustion or industrial systems which favour dioxins formation and besides, transition metals in the synthetic materials do not only provide favourable temperatures for dioxin formation but also acts as catalysts for their formation [136]. Scientific surveys have revealed that the presence of salts of transition metal catalysts and chlorine in the combustion system or forest fires, or incineration atmospheres favours the formation of PCDD/Fs [79]. In order to reduce emission of dioxins into the environment from thermochemical processes for instance pyrolysis and combustion processes, it has been proposed that a combination of stringent measures would be fundamentally helpful; (1) incineration activities to be conducted at a temperature in excess $1000^{\circ} \mathrm{C}(2)$ increasing the pyrolytic contact time and the total pyrolysis time (3) use of flue gas filtration (4) employing well-designed modern incinerators [135]. In some countries such as the United States, emission of dioxins from burning of solid fuel, forest fires and medical waste incinerators has become increasingly difficult to control [111]. The most recent concern about the formation of these pollutants is the recycling of electronic wastes in poorly controlled conditions, which ultimately favour the formation of PCDD/ Fs [40, 132].

Generally, the pyrolytic processes for the generation of dioxins are classified as either homogeneous and take place between 500 and $800{ }^{\circ} \mathrm{C}$ mainly in the gas-phase or heterogeneous occurring at a temperature window of 200 and $400{ }^{\circ} \mathrm{C}$, and comprise mainly gas-solid phase reactions [105]. PCDD/F precursors are proposed to form in the pyrolytic or combustion environment at temperatures above $1000^{\circ} \mathrm{C}$, but formation of PCDD/Fs can be controlled by varying the residence time during the cooling of reaction products especially when cooling takes place between 250 and $650^{\circ} \mathrm{C}$. The maximum temperature for the formation of PCDD/F has been estimated at about $300^{\circ} \mathrm{C}$ [105].

\subsection{Mechanistic formation of dioxins}

Formation of dioxins is a proven complex reaction process involving multiple solid and gas phase reactions with dioxins formed alongside other combustion gases, fly ash and slag $[67,85]$. Dioxins and furans are also considered as the products of incomplete or uncontrolled decomposition of

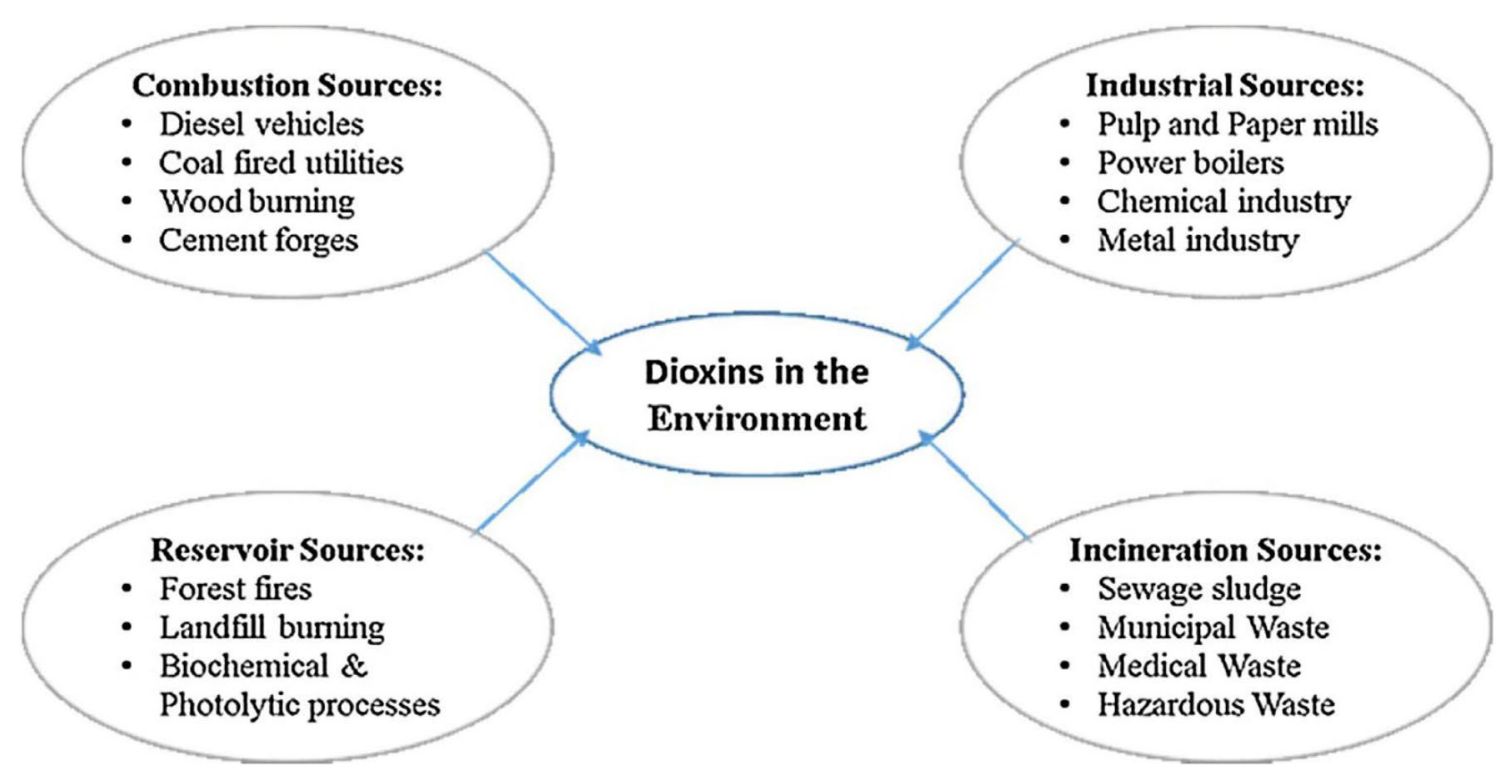

Fig. 2 Major sources of dioxins in the environment adapted from Weber et al. [125] 
anthropogenic wastes, biomass degradation and wildfires; emission of chlorinated dioxins and chlorinated dibenzofurans from anthropogenic activities escalated by synthetic substances and possible additives and the introduction of a transition metal catalyst such as copper or iron in presence of chlorinated materials into the system [94, 103]. Combustion and environmental scientists have proposed two mechanistic processes associated with the formation of dioxins and furans during combustion, namely; the De novo synthesis which starts from macromolecular carbon or polycyclic aromatic hydrocarbons (PAHs) and the precursor synthesis which is initiated by an organic molecule similar to dioxins [113]. Transition metal species, specifically copper and iron, exert a strong catalytic effect on PCDD/PCDF formation via the two heterogeneous routes-De novo and precursor synthesis [1].

Both of these mechanistic channels proceed either simultaneously or independently [62]. Precursor synthesis has, nonetheless, been found to be more predominant over the De novo mediated route at elevated temperature conditions [85]. However, at lower temperature, the de novo mechanism dominates [50]. Previous studies have also suggested that the formation of dioxins and dioxinlike compounds from combustion events approaches a maximum at a temperature of about $300^{\circ} \mathrm{C}$ while their precursors are formed at a temperature above $1000^{\circ} \mathrm{C}$ [126]. Furthermore, cooling combustion products between 250 and $650^{\circ} \mathrm{C}$ significantly controls emission of dioxins into the atmosphere and subsequently to the biota environment [94]. According to the two mechanistic pathways, the formation of PCDD/Fs from thermal processes is favoured by a number of conditions [1, 109]: (1) the presence of a fixed carbon source, or fly ash to propagate the de novo synthesis in the post-combustion or cooling region; (2) availability of chlorine which precipitate the formation of chlorinated species during combustion, and after cooling of the exhaust gases (3) the presence of a transition metal such as copper and iron to catalyse the formation of dioxins and/or furans (4) appropriate temperature preferably between 473 and $873 \mathrm{~K}$ (5) favourable fuel in the cooling region which ideally should contain between 10 and $15 \%$ oxygen (6) precursor compounds specifically those containing aromatic ring structures.

\subsubsection{The De novo synthesis of dioxins and furans}

The De novo synthesis is influenced by reaction temperature, residence time and total pyrolysis time, carbon, chlorides and catalyst in fly-ash and gas-phase composition in which the evident association with chloroaromatic classes of compounds such as chlorophenols (CP), chlorobenzenes $(\mathrm{CBz})$, polychlorinated biphenyls $(\mathrm{PCB})$, and polycyclic aromatic hydrocarbons $(\mathrm{PAH})$ is also considered
[134]. In this mechanistic pathway, the formation of dioxins involves the chlorination of carbon via the transfer of chloride by $\mathrm{CuCl}_{2}$ (cf. Scheme 1 and Fig. 3), followed by the oxidation of the chlorinated matrix at $250-450{ }^{\circ} \mathrm{C}[114$, 134]. This temperature range is lower than the oxidative temperature of pure carbon estimated at $550{ }^{\circ} \mathrm{C}$-the lower temperature is achievable by using $\mathrm{CuCl}_{2}$ as the catalyst $[107,108]$.

The oxidative process generally yields $\mathrm{CO}_{2}$ and $\mathrm{CO}$, with the evolution of trace quantities of aliphatic and aromatic compounds such as chlorobenzenes ( $\mathrm{CBz})$, chlorophenols (CP), PCDD/Fs [50, 134], however; in order to significantly lower the rate of production of PCDD/Fs in the De novo synthesis, the concentration of oxygen fuel should be lowered to less than 2\% [106]. Several researchers have accepted the important role of $\mathrm{CuCl}_{2}$ as a catalyst for chlorine formation as shown by the Deacon's reaction [122] expressed by Eq. 1. The chlorine formed reacts with carbonaceous matrix in the De novo synthesis [130].

$2 \mathrm{HCl}+\frac{1}{2} \mathrm{O}_{2} \rightarrow \mathrm{Cl}_{2}+\mathrm{H}_{2} \mathrm{O}$

The presence of elements, notably; chlorine, oxygen, and copper is necessary for PCDD/F formation in the De novo synthesis, but contribution of combustion gasses such as $\mathrm{CO}$ or $\mathrm{CO}_{2}$ in the formation of polychlorinated dibenzofuran (PCDF) by this mechanism is remarkably insignificant [1]. Besides the concentration of oxygen, the activity of fly ash also controls the rates of formation of $\mathrm{PCDD} / \mathrm{F}$, therefore, since the chlorine in this dioxin synthetic pathway originates from the chloride salt of a transition metal ordinarily found at the surface of fly ash, the contribution of the concentration of chlorine in the combustion gaseous mixture is insignificant [71]. The numerous products generated from the De novo synthesis are in the following order of prominence $C B z>C P>P C D F s>P C D D s>d l-P C B[41,83,134]$.

\subsubsection{The precursor synthesis of dioxins and furans}

Precursors are chemicals that initiate a reaction for instance in the formation of dioxins, furans and their associated analogues and include chlorophenols (CP), chlorobenzenes $(\mathrm{CBz})$, and polyaromatic hydrocarbons (PAHs) in addition to oxygenated compounds that are structurally similar to dioxins $[76,105]$. These precursor compounds form dioxins through chlorination, condensation and oxidation processes [106]. The mechanistic formation of PCDDs and PCDFs are dissimilar (Schemes 2, 3) and this has proven that the content of PCDFs is usually in higher yields than that of PCDDs $[113,131]$.

Most combustion researchers have noted the importance of residual carbon in the synthesis of PCDD/Fs which 
<smiles>Oc1ccccc1</smiles>

Deacon's reaction catalyst hydrogen chloride

\section{chlorination of aromatic precursors}

molecular products

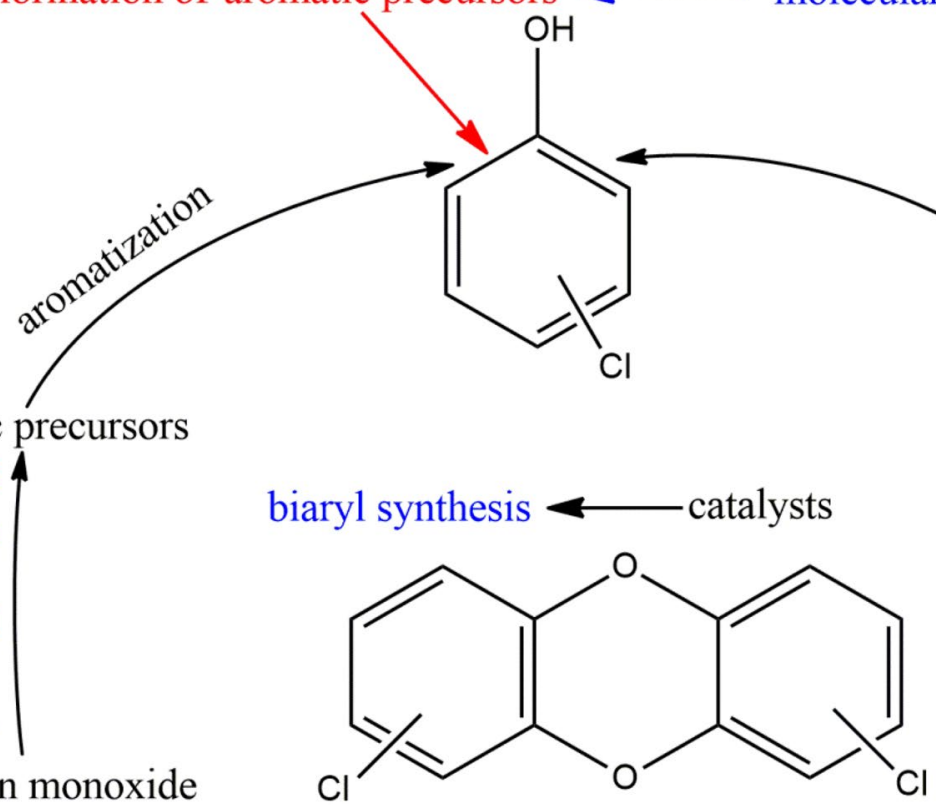

\section{carbon monoxide} carbon dioxide

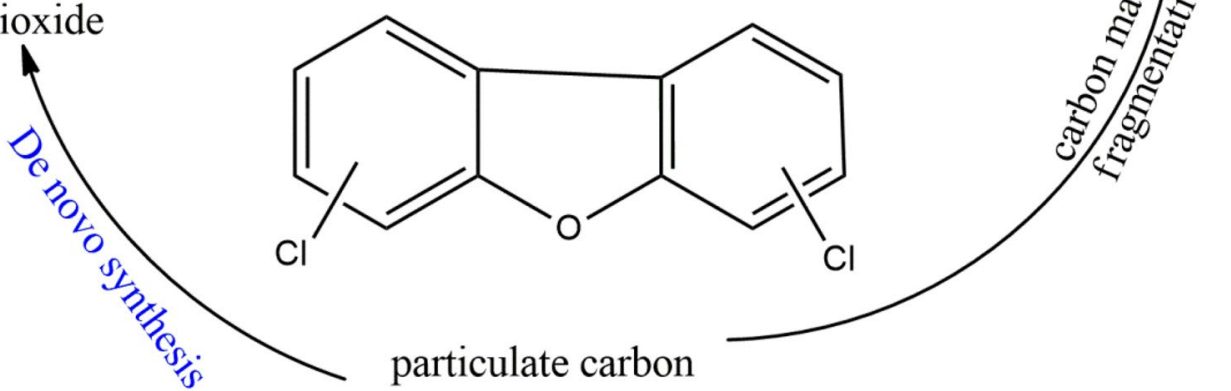

Scheme 1 The De novo and precursor synthesis of dioxins and furans Modified from Tuppurainen et al. [114]

interestingly show that the release of PCDD/Fs is directly proportional to the rate of consumption of carbon [54]. The formation of PCDDs is believed to be a sequential multistep reaction that proceeds by coupling of chlorophenol-often a surface catalysed mechanism involving ring closure which proceeds via a catalytic process by an electron donor oxidant whose role is to enable the coupling of two benzene rings as shown in Scheme $2[76,105]$. This mechanism also proposes the formation of polychlorodibenzofurans (PCDFs) from the combustion chamber from where chlorine is released in form of $\mathrm{HCl}$ which ultimately reacts with products formed from incomplete combustion to generate dioxin precursor compounds (Scheme 3), notably chlorinated phenols and benzenes at a temperature of about $450^{\circ} \mathrm{C}$ [131].

The mechanism shown in Scheme 3 explains that PCDD is formed via a heterogeneous reaction aided by heterogeneous catalysis [93]. This process is characterized by the following steps (a) creation of fly ash and incomplete combustion products (b) formation of surface-active molecular precursors (c) complex organic radical reactions and (d) partial desorption of products [127]. Chlorinated phenols such as 2-monochlorophenol (2-MCP) and benzenoids (benzenes) at a temperature window of $200-450^{\circ} \mathrm{C}$ then 
Fig. 3 The De novo mechanism of dioxin formation Adapted from Environment Australia [18]

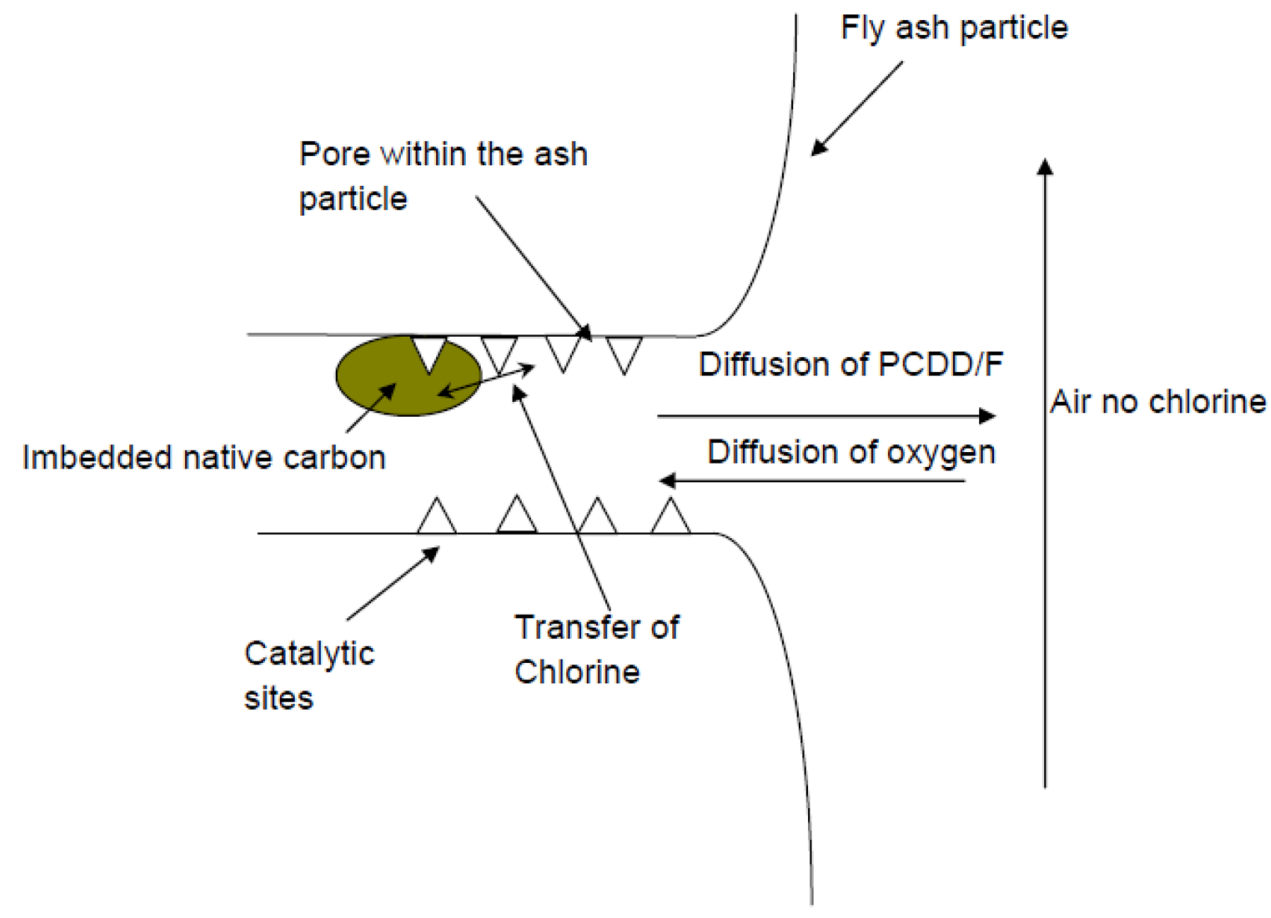

undergo both condensation and de-chlorination reaction processes which are catalytically induced $[76,114]$. Polychlorinated benzenes are suggested to form by either radical mechanisms or by the combination of chlorine and chlorobenzyl radicals [127]. Eventually, the addition of two chlorobenzyl radicals gives rise to polychlorinated biphenyls, PCBs, which are possible precursors for the formation of PCDFs [71, 131].

The De novo mechanism suggests that there are structures similar to the dibenzo- $p$-dioxins and dibenzofurans in the residual carbon attached to the fly ash [127]. One major difference between the De novo mechanism and the pyrosynthesis mechanism is that the De novo mechanism leads preferentially to the formation of polychlorinated dibenzofurans (PCDDs) whereas the precursor pathway favours the formation of polychlorinated dioxins (PCDDs) [103]. Burning uniform fuel at elevated temperature at relatively enhanced residence time and at reduced chlorinated-sulphur ratios are key to the lowering of PCDD/Fs formed $[6,60]$.

\section{Toxicokinetics of dioxins}

Dioxins find their way into animal and human biological systems through ingested food or possible inhalation from polluted gas-phase regimes [16, 26]. Absorption of dioxins into the human body through ingested foods depends mainly on the carrier; for instance, dioxins in the soil environment are less absorbed than those in fish and other animal products such as eggs, milk and meat [9]. The pharmacokinetics of dioxins and its related analogues largely depend on the species type, carrier, specific congener and the quantity ingested [124]. In all animals, $2,3,7,8$ substituted PCDD/Fs are not easily eliminated from tissues especially from the liver and fats $[55,123]$. Dioxins which may be absorbed through the skin, find their way into the adipose tissue and ultimately into the liver from where they are slowly metabolized for elimination from the body [121]. It is on record in scientific research that the dermal absorption of dioxins depends on the type of the congener [9].

Evidently, dioxins are not easily metabolized and consequently this makes their elimination or degradation extremely slow [97]. Nonetheless, dioxins are eliminated through faeces and negligibly via the kidneys in form of urine [104]. There is an enormous variation in the half-lives of 2,3,7,8-tetrachlorodibenzo- $p$-dioxin (TCDDs) species, for instance, it has been documented that in rats, the halflife of TCDD is 3 weeks while in humans; the half-life is reported to be 7 years, but again, half-lives of congeners in humans is age dependent with children having short half-lives of congeners compared to adults - this is attributed to the higher rate of metabolism and faecal excretion in children than in adults $[48,59]$. There is also a significantly huge individual disparity in elimination half-lives of congeners, for instance high concentrations of congeners instigates a high release of enzymes responsible for metabolism thereby leading to a shortened half-life of the congener $[69,104]$. Previous studies on the elimination 


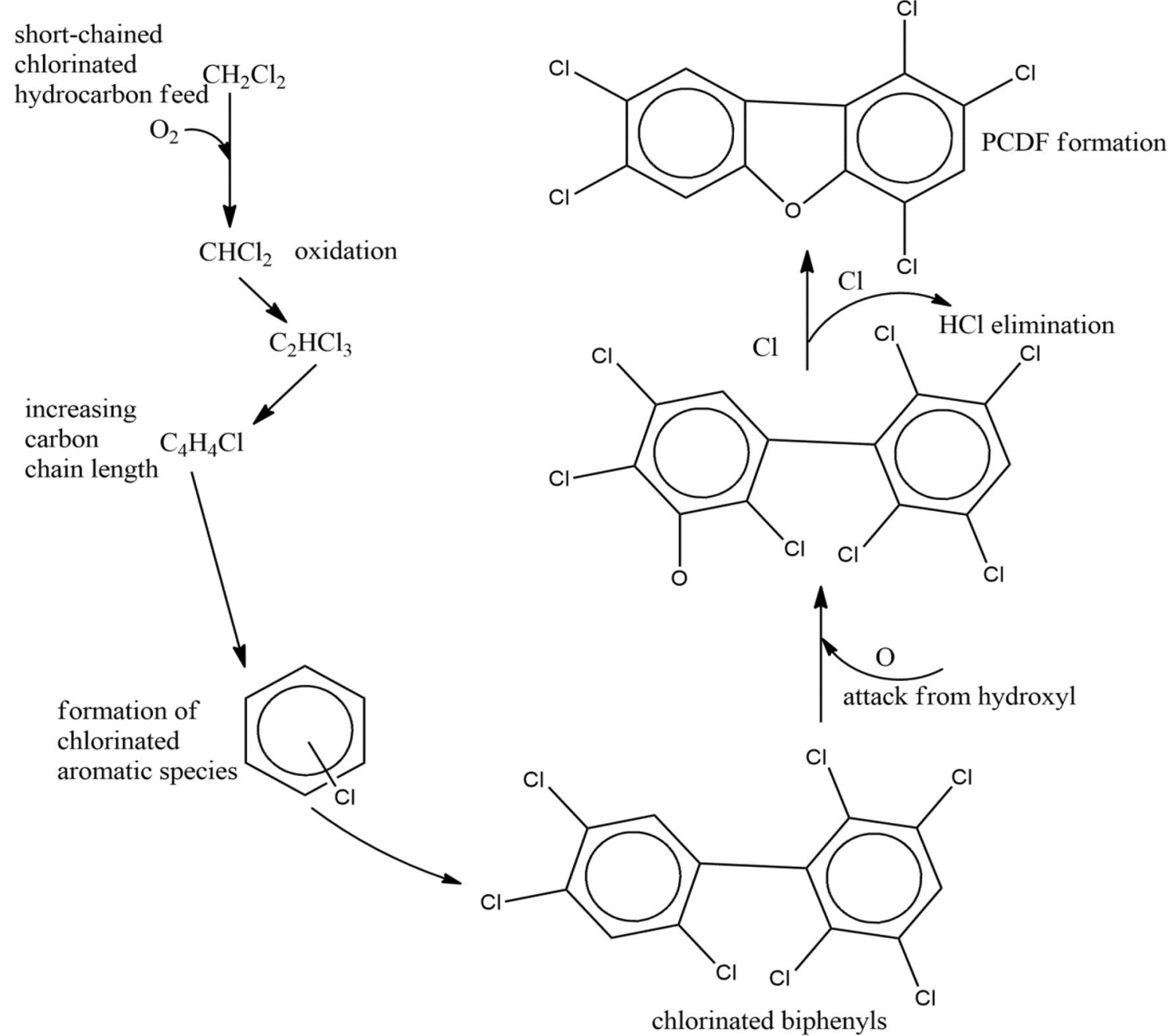

Scheme 2 Proposed homogeneous pathway for the formation of PCDF Adapted from Environment Australia [18]

of dioxins have reported that maternal dioxin levels decrease during the lactation period by nearly $20 \%$ [119]. Furthermore, the concentration of dioxins and/or furans in the placenta almost equals those in the maternal body or those found in the breast milk in the region of $\mathrm{pg} / \mathrm{g}$ fat content [121] and this therefore makes it possible for transfer of dioxin or dibenzofuran to the foetus which may actually be fatal [24].

Research on the elimination rates of dioxins and/or furans [70], have shown that elimination rates can be determined using a model developed by van der Molen et al. [117] which has been established to differ from the exponential model because it relies on the following assumptions; (1) body weight and intake rate entirely depend on age (2) elimination rate is dependent on body composition (3) background intake is a function of time and thus should be treated as an input. However, this model does not advocate for the subtraction of the background steady state concentration of dioxins from the observed concentration among the affected persons [70]. According to van der Molen et al. [117], body composition, body weight and intake rate vary with age and that elimination takes place from the liver at a rate that is proportional to the actual concentration of dioxin in the liver, $\left[\mathrm{A}_{1}\right]$ and liver weight, $\mathrm{W}_{1}$, with elimination rate $\mathrm{k}$. Thus the change in the total amount of dioxin in the human body,A, can be expressed by Eq. 2 .

$\frac{d}{d a} A\left(a ; t_{b}\right)=F\left(a+t_{b}\right) I(a)-k\left[A_{1}\right]\left(a ; t_{b}\right) W_{1}(a)$

From the equation, a denotes age, $t_{b}$ is time of birth, the term $F\left(a+t_{b}\right)$ corrects for historical changes in the intake rate whereas $I(a)$ is the age dependent intake rate.

This model asserts that the human body is sub-divided into a total of six compartments, each with a given percentage of lipids which do not vary with age [70]. The lipid 


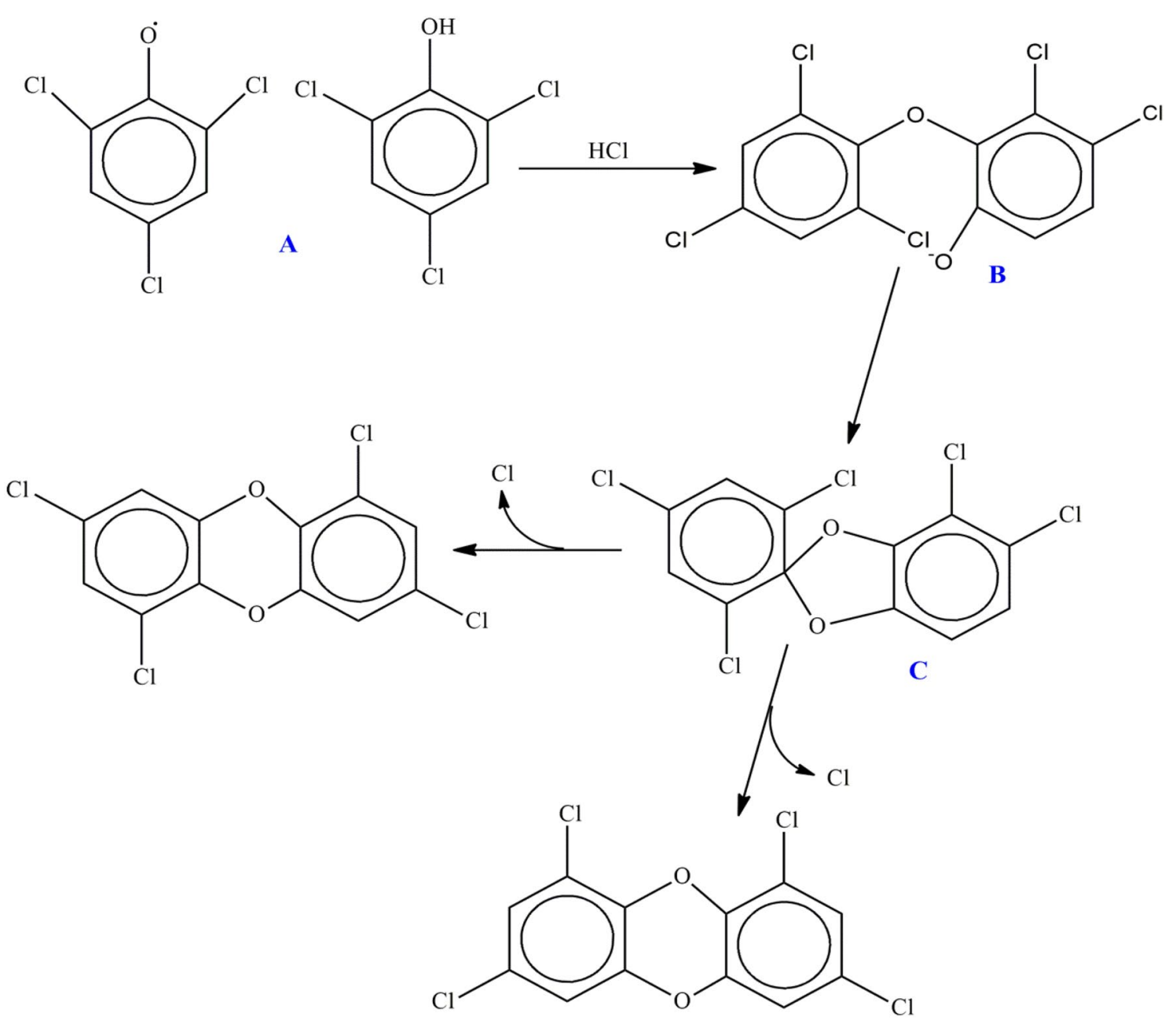

Scheme 3 Formation of PCDD from 2,4,6-trichlorophenol catalysed by fly ash Adapted from Tuppurainen et al. [114]

portion in each compartment influences the distribution of dioxins/furans over the human body in line with the assumption that the quantity or concentration of these dioxins and furans is equal in all the compartments on the basis of lipid weight [117]. On this basis, Eq. 2 reduces to the Eq. 3, which illustrates that, the elimination of dioxins/furans from the body is a first order process with elimination ratekX(a) which is age dependent.

\section{The toxic equivalency factors (TEFS) and toxicity equivalence (TEQ) of dioxins}

Based on the assumption that dioxins and their associated analogues exhibit similar mechanistic action and characteristics from various experimental studies, it is generally accepted that their individual toxicities are summative [118]. Accordingly, toxic equivalence factors

$\frac{d}{d a} A\left(a ; t_{b}\right)=F\left(a+t_{b}\right) I(a)-k X(a) A\left(a ; t_{b}\right) W_{1}(a)=F\left(a+t_{b}\right) I(a)-k \frac{W_{f, j}(a)}{\sum_{j} W_{f, j}(a)} A\left(a ; t_{b}\right)$

where $X(a)$ is the amount of dioxins in the liver, which is age dependent and a fraction of the total amount of dioxins in the body and equals the ratio between the lipid weight of the liver, $\mathrm{W}_{\mathrm{f}, \mathrm{j}}$ and the total body lipid weight $\sum_{\mathrm{j}} \mathrm{W}_{\mathrm{f}, \mathrm{j}}[70]$.
(TEFs) are generally used to estimate the human risk of dioxins and dioxin-like chemicals using predominantly blood levels or other body fluids despite the fact these TEFs are derived based on intake doses in animal studies such as rodents [118]. From a toxicological perspective, dioxins, dibenzofurans and poly halogenated aromatic hydrocarbons such as polychlorinated biphenyls (PCBs) 
occur as a complex mixtures in the environment causing adverse health concerns to humans and other vertebrates, and exhibit varied toxic indices among organisms [111]. Determination of the toxicity or the potency of a mixture of toxins is not done by summing up the concentrations or amounts of the components, however, as long as the amount of a compound is standardized to the toxicologically equivalent amount of 2,3,7,8-tetrachlorodibenzop-dioxin (TCDD), components of a mixture with different potencies is usually totalled and the equivalent quantity is useful for regulatory measures $[13,126]$. By use of their common mechanistic action, dioxin and dioxin-like compounds, a toxicity ranking scheme has lately been used to assign toxic equivalence factor (TEF) to each molecule relative to the most toxic dioxin, TCDD [118]. The main reason for developing the toxic equivalent factors was to estimate the potential health effects of a particular dioxin congener or dioxin mixture [126]. A TEF enables comparative toxicity analysis for a molecule whose toxicity information is unknown versus another molecule whose toxicity index and mechanism of toxicity is known [7]. For dioxins, the most toxic and prototype dioxin to which all the other dioxins are compared to is $2,3,7,8-\mathrm{TCDD}$ [118].

In addition to their similarity in structure, dioxins and benzofurans have planar molecular conformations [38]. The similarity in molecular conformation explains their similarity in their toxic characteristics [116]. Toxic equivalence factors (TEFs) are assigned to a compound based on the experimental data for a dioxin relative to TCDD [115], thus, the TEF assigned for TCDD is 1, and it is less than 1 for all other analogues of TCDD. The TEF allows the comparative numerical analysis of a toxicity of a molecule in terms of an equivalent concentration of TCDD [37]. In this comparison, known TEFs values for the individual dioxins or dioxin-like components, and their concentrations in the mixture, can be exploited in the evaluation of total toxic equivalence (TEQ) for the mixture [111]. The TEQ is calculated as the sum of the individual products of the TEF and the concentration of each compound as expressed by Eq. 4 $[22,96]$ and thus the concentration of each compound is multiplied by its toxic equivalence factor. The summation of the values obtained constitutes the total toxicity relative to the most toxic dioxin $2,3,7,8-\mathrm{TCDD}$ [111].

Total equivallent toxicity $(T E Q)=\sum_{n=1}^{k} C_{n} \times \operatorname{TEF}_{n}$

\subsection{Common molecular action of dioxins}

Dioxins largely exercise their biochemical action such as toxicity on vertebrates via the activation of the aryl hydrocarbon receptor, AhR [31, 47, 129], a ligand-activated basic helix-loop-helix transcription factor and a member of the PER-ARNT-SIM (PAS) superfamily of transcription factors [31]. Dioxins bind specifically and firmly to the aryl hydrocarbon receptor (AhR) upon entry into the cell, leading to the excitation of numerous enzymes responsible for its detoxification or elimination from the body [20]. Although AhR is apparently a conserved protein found in vertebrates, other related proteins have been known in invertebrate species such as Caenorhabditis elegans and Drosophila species [34]. Further to its role as a transcription factor, AhR plays critical roles in the regulation of the neural development, daily rhythmic functions, and ageing [8]. The AhR in its non-ligand bound state in the cell exist solely as cytosolic complex with chaperones which include the heat shock protein (Hsp) 90 and prostaglandin E synthase 3 (p23), hepatitis B virus and X-associated protein 2 (XAP2) [129]. The AhR originally believed to be involved in drug metabolism and mitigating carcinogenic effects has also been proven to participate in toxicological actions against environmental contaminants, including the most toxic dioxin congener, 2,3,7,8-tetrachlorodibenzo- $p$-dioxin (TCDD) and possible other dioxin-like chemicals [47].

In the cell, TCDD binds to AhR to form AhR-complex which translocates into the nucleus [20]. Here in, transcription of genes occurs after AhR heterodimerizes with AhR nuclear translocator (ARNT) [8] leading to the production of the well-known protein; cytochrome P-450 (CYP) 1A [88]. There are several other enzymes whose expression is affected by exposure to dioxin and dioxin-like compounds some of which include; an aldehyde dehydrogenase and NADPH-quinone-oxidoreductase enzyme [88]. The AhR complex also affects the expression of other genes that influence basic cellular processes such as growth, differentiation and programmed cell death $[14,88]$. Additionally, in the nucleus, AhR releases the bound ligand before it heterodimerizes with another protein such as AhR nuclear translocator (ARNT) [111]. The resulting dimer readily binds to DNA [82]. When interaction of dioxins and AhR occur which also involves the retinoid system, the biological action of dioxins will include retarded growth, problems associated with reproduction, and in some cases, developmental impairments $[3,77,104]$. These observed effects of dioxins are attributed to their participation in the metabolic steps of the retinoid activation and metabolism as well as in molecular interactions of the retinoid receptors and AhR in the transactivation system [77]. As a response to the activation by dioxins, the AhR signalling pathways regulates the expression levels of various genes by induction of the gene for a Phase I cytochrome P-450 drug-metabolizing enzyme, CYP1A1 [20, 65, 81, 82], an enzyme involved in oxidation, reduction, and hydroxylation reaction processes $[14,88]$. The initiation of changes in the expression of these genes begins with the ligand 
binding to the AhR [88]. Generally, induced toxicity via the activation of AhR, prevents AhR from performing its functions, which importantly, includes the maintenance of homeostasis $[47,129]$.

\section{Analytical methods for the determination of dioxins and furans}

The analysis of dioxins can be done using either chemical and/or biochemical techniques also referred to as bioanalytical detection methods. The chemical instrumentation for analytical methods include the use of chromatographic techniques mainly gas chromatography (GC) and high performance liquid chromatography (HPLC) coupled with various detection methods including mass selective detector, MSD, electron capture detection, ECD, and photodiode array detector, PDA [80]. The widely acceptable and most useful biological methods are based on binding bioassays, biomarkers, cell and/or organ bioassays and in vivo bioassays or laboratory exposure [80]. Of these analytical techniques, chemical instrumental analysis remains the most effective technique because polyhalogenated aromatic hydrocarbons (PHAHs) of interest can easily and effectively be separated and quantified; nonetheless, the limitations of any particular analytical tool for determining dioxins and furans can be overcome by using a combination of both chemical analytical methods and biological techniques [80]. Bioanalytical methods have certain limitations $[17,35]$ which include; (1) possible lack of degree of reliability (2) absence of cross-validation database for different bioassays (3) limited inter laboratory cross-validation studies obtained from similar technology (4) absence of international and national scientific data for various complex matrices (5) limited predictive battery from a toxicological standpoint because of the necessity for in vivo-in vitro extrapolation and (6) lack of international accepted quality criteria for analysis.

\subsection{Methods based on chemical analysis}

In these methods, dioxin and dioxin-like compounds are separated and quantified by utilizing their physical properties not limited to molecular size, polarity, charge and redox potentials $[88,102]$. The popularity of this method can be attributed to the structural conformations, the specificity of a particular congener of interest and the fact that chemical based methods enables calculation of toxic equivalence (TEQ) indices [88]. Despite its wide applicability and general approval of the chemical instrumental analysis, these methods have limitations such as long analysis timelines, high-priced costs, and refined technical expertise in order to get accurate results, and lacks explanation on the biological potency and possible interaction of dioxin-like chemicals in a given matrix [110]. The cutting-edge method which has been employed in recent years for the separation and quantification of dioxins and dioxin-like compounds is the high resolution gas chromatography (HRGC) hyphenated to the high resolution mass spectrometer (HRMS) [88]. Other techniques include HPLC coupled with supercritical fluid extraction (SFE) mainly for recoveries of PCBs and PCDDs, and have merits such as low solvent consumption and shortened extraction times [88].

\subsection{Immunoassays}

This technique employs the use of antibodies to detect a particular dioxin congener and the method is thought to be one of most robust in the detection of dioxins and its analogues [87]. Some of the conventionally used immunoassay are for instance, radioimmunoassay (RIA), Fluorescence immunoassay ( $\mathrm{FI})$, and the enzyme-linked immunoassay (ELISA) $[20,110]$. ELISA methods are rapid in screening dioxins and/or furans, and dioxin-like chemicals because this method utilizes the ability of particular anti-bodies of high specificity to select and reverse bind to a dioxin [110]. The ELISA kits contain binder molecules, labelled ligands, coated antigens, target analyte which can react to equilibrium so that the ligand molecules are enabled to bind with an enzyme, a fluorescent molecule, and a radioactive tracer where the fraction of bound molecules forms the basis for their measurement $[100,110]$. Therefore, dioxin-AhR interaction is one of the probable inexpensive alternatives to numerous analytical techniques for detecting dioxin contamination in the biological environment [20].

\subsection{In vivo biomarkers}

This method is associated with the biological changes as a result of exposure to a specific contaminant in the environment, and mainly detects physiological and biochemical changes induced as a result of exposure to dioxins [110]. In this method, dioxin levels in body tissues are determined using biomarkers, mainly, DNA and enzymes [87]. Scientific surveys have established that there is a close relationship between exposure to a specific dioxin in the environment and in vivo biomarker response [35]. With regard to studies on exposure of dioxins to humans, fish and aquatic animals; the induction of cytochrome P450 1A gene (CYP1A) has been extensively used as a biomarker because the induction occurs as a result of binding of dioxin or furan to the AhR receptor [87]. These studies reported a strong correlation between toxicity of the dioxin congeners and induction of CYP1A $[25,51]$. 


\subsection{Biochemical method involving the use of lower ranked synthetic peptides}

Owing to the limitation of higher ranked peptides being unable to bind to dioxins, currently, short peptides is fast substituting immuno antibody method in the detection of dioxins in a given sample matrix [87]. Previous studies on biological analysis of dioxins have demonstrated that peptides can be used as sensors for low molecular weight compounds [88]. More recently, pentapeptide has been generally used in the assessment and detection of dioxins where the peptide head upon being screened by a fluorescence microscope can detect dioxins with high level of sensitivity [102]. The interaction between dioxins and peptides has been useful industrially in designing a peptide based material which is highly sorbent to the toxic dioxin, 2,3,7,8-tetrachlorodibenzo-p-dioxin (TCDD) [88].

\subsection{In vitro bioassay: DNA binding bioassays}

This method of analysis is based on the ability of a dioxin to transform AhR receptor into a DNA binding form on the condition that the AhR receptor has suitable ligands [87]. The technique relies on electrophoretic mobility shift method which estimates the DNA binding and AhR transformation; to do this, the technique is based on the detection of AhR-DNA complexes that are formed and their mobility during electrophoresis [17]. Despite its high sensitivity, this technique has some serious limitations $[68,110]$ which include (1) inability to differentiate between receptor antagonist and AhR agonist and which may result in false positive data (2) it may not detect synergistic effects of dioxins and furans in a given environmental sample matrix (3) lack of quality control and thus unreliable results.

\subsection{Sensor techniques}

Lately, most researchers have opted for the sensor technique because it is easy, affordable and has the ability to provide unrivalled real time analysis $[11,21]$. Biological and physical techniques have been found to be the most promising, popular and applicable in the determination of dioxins in the environmental sample matrices across all food chains [21]. Even though physical sensors are reputed for their high sensitivity and specificity, they cannot detect the level of biological toxicity as expressed by toxic equivalency factor (TEF) and the toxicity equivalence (TEQ) index [35]. Biosensor technology is used to determine the concentration of dioxin contamination in food products, and has also found its applicabilition in public health and medical care as well as in environmental monitoring and assessment [26]. Biosensors are reliable, accurate and deliver real time analysis; low energy cost, uses less chemical reagents, and minimizes waste production [21].

Biosensors consist of two components; a biorecognition element also known as the biochemical receptor for recognizing the target contaminant and a transducer that converts the event into an electronic signal [120]. Immunosensors show high sensitivity to dioxins and dioxin-like compounds and in order to detect dioxins in fly ash, immunosensors use quartz crystal microbalance as a transducer and binds to TCDD derivatives at a lower detection limit of 1 part per trillion [53]. Some studies reported that the microorganism Pseudomonas sp. P2 can be used as a recognition element for optical detection [28]. Gavlasova et al. [28] reported that upon oxidizing the dioxins and dioxin-like compounds, the microorganism produces yellow meta ring-fission metabolites that can be measured through the absorption spectra by an optical transducer. This technique has successfully been used in the detection of PCB in soil samples. Nonetheless, a new sensor technique known as biomimetic based biosensors have been used, this technique uses a synthetic recognition element that is designed to mimic the natural biochemical receptors such as antibodies and enzymes [120]. Another study, by Mascini et al. [66] determined dioxins and dioxinlike compounds in food products using the biomimetic approach combined with quartz crystal microbalance piezoelectric transducer-in their study, they synthesized oligopeptides to mimic aryl hydrocarbon receptor binding sites and reported that the range of detection of TCDD, a dioxin mixture and PCBs was from 1 to $5 \mathrm{ppb}$ and 1 to $10 \mathrm{ppb}$, respectively.

\section{Environmental degradation of dioxins, furans, and their related analogues}

Dioxins and furans form a group of the most notorious environmental toxicants due to their stability towards physical, chemical and microbial degradation [48]. They are classified as persistent organic pollutants (POPs) for centuries and even beyond, and are therefore a threat to generations to come [52]. The toxicity of dioxins to humans, wildlife and ecological systems in general has been enhanced by their properties such as hydrophobicity and bioaccumulation [111]. Their hydrophobicity makes them strongly adsorbed onto the surfaces of organic materials and soil components [93]. Several approaches have been explored to free PCDD/Fs from contaminated systems; some of these approaches include physical and chemical interventions [48]. Dioxins are reported to be quite inert to chemical degradation and this has made their removal from the environmental 
sites an enormous challenge [52]. The use of dioxin inhibitors such as sulphur and nitrogen, dechlorination aided by metal catalysts, pyrolysis and photodegradation are some of the recently explored physicochemical remediation measures to detoxify the environment from dioxin and furan contamination [93]. The congener, 2,3,7,8-tetrachlorodibenzo- $p$-dioxin (TCDD), has been reported to be very sensitive to photochemical dechlorination and is suggested to be destroyed within hours when exposed to direct sunlight [12]. Physicochemical methods of removing dioxins are not cost effect, besides, dioxins display inertness to chemical remediation such as the use of alkali metal hydroxide $(\mathrm{KOH}) /$ polyethylene glycol (APEG) [10]. Thermal remediation similarly has its limitations, for instance, it cannot be applied to most mediums especially those that do not readily undergo thermal degradation at reasonably high temperatures $>600^{\circ} \mathrm{C}$ [24].

The use of microorganism has lately been an attractive biological approach in dioxin and furan degradation because of factors such as economic feasibility, environmental compatibility and flexibility, and the fact that microbial degradation cannot introduce other toxic substances to the environment but instead convert the toxicants into $\mathrm{H}_{2} \mathrm{O}, \mathrm{CO}_{2}$, and $\mathrm{CH}_{4}[9,10]$. Studies on microbial detoxification of the environment from dioxins, that is, $\mathrm{PCCD} / \mathrm{Fs}$, non-chlorinated dibenzofurans have been used as a blueprint chemical strategy [9]. These studies have reported that highly substituted congeners of dibenzofurans and dibenzo- $p$-dioxins can be degraded by some bacteria strains such as Nocardioides aromaticivorans, Terrabacter sp. strain DPO360 and Pseudomonas putida [111]. This clean-up of the environment by bacterial degradation of PCDD/Fs involves both aerobic and anaerobic processes $[12,99]$. It is important to note that the reaction products of these catabolic reactions can be mineralized further and directed into the biogeochemical cycle because incomplete degradation can result into the formation and accumulation of more toxic metabolites that can be more toxic than their primary substrates [97].

Degradation of carbazole by Pseudomonas stutzeri has been found to be an important biosynthetic route to L-tryptophan where anthranilic acid is formed as an intermediate metabolite $[44,99]$. Jaiswal et al. [43] studied the degradation of dibenzofuran using Pseudomonas sp strain by angular deoxygenation route described in Scheme 4 [99]. Other studies $[58,89]$ have also proposed the use of a combination of photolytic catalyst, mainly titanium dioxide $\left(\mathrm{TiO}_{2}\right)$ with UV light to degrade dioxins and its analogues in the soil environment by oxidizing the organic substances in the soil into water, carbon dioxide and possibly methane.

\section{Nitrogenated analogues of dioxins, dibenzofurans and their comparative toxicity}

Nitrogen containing analogues of dioxins and dibenzofurans display similarities in structure in which the $\mathrm{NH}$ group replaces oxygen in the dioxin of furan structure (Fig. 4). Some of these aromatic polycyclic compounds are for instance carbazoles including chlorinated and brominated versions and 9H-pyrido[3,4-b]indole [73]. However, halogenation of carbazole is a key subject in medicinal chemistry and materials science and for this reason they are starting materials for the synthesis of numerous bioactive molecules of pharmaceutical importance despite their well-known toxicological characteristics [91].

These nitrogen containing heterocyclic compounds such as the mono- and polyhalogenated carbazoles (PHCZs) which are commonly known as nitrogenated dioxins are suggested to originate from either anthropogenic or natural sources and have been reported to possess toxicities comparable to those of dioxin and furan compounds basically because of their structural similarities [92]. From a chemical standpoint, the toxicity of polyhalogenated carbazoles ( $\mathrm{PHCZs}$ ) has been attributed to their resemblance with polychlorinated dibenzo- $p$-dioxin and dibenzofuran, with very close correlation between their planar molecular conformation and dioxin-like toxicological characteristics [23]. Carbazole in particular has been reported in literature to be both carcinogenic and mutagenic [45]. However, because this class of compounds is treated as emerging toxicants, very limited information is available in literature concerning the mechanism by which these nitrogenated dioxins manifest their toxicity. Nonetheless, recent studies on halogenated carbazoles have reported the potential to activate aryl hydrocarbon receptor (AhR) using in vitro cell assays, with the potency of these compounds reported to be largely dependent on the degree and position of halogenation of the carbazole molecule [72, 92].

Although the N-homologues of dioxins may not have been listed as priority contaminants, it is reported that they have properties very similar to those of persistent organic pollutants (POPs) but of great concern is the fact that these dioxin and furan analogues are resistant to degradation in the soil, with carbazole and dibenzopyrrole mainly found in crude oil being quite recalcitrant to elimination or degradation $[99,133]$. However, some microorganism, especially certain bacterial strains of the Pseudomonas stutzeri type has been reported to degrade these nitrogenated compounds (carbazole) as a source 

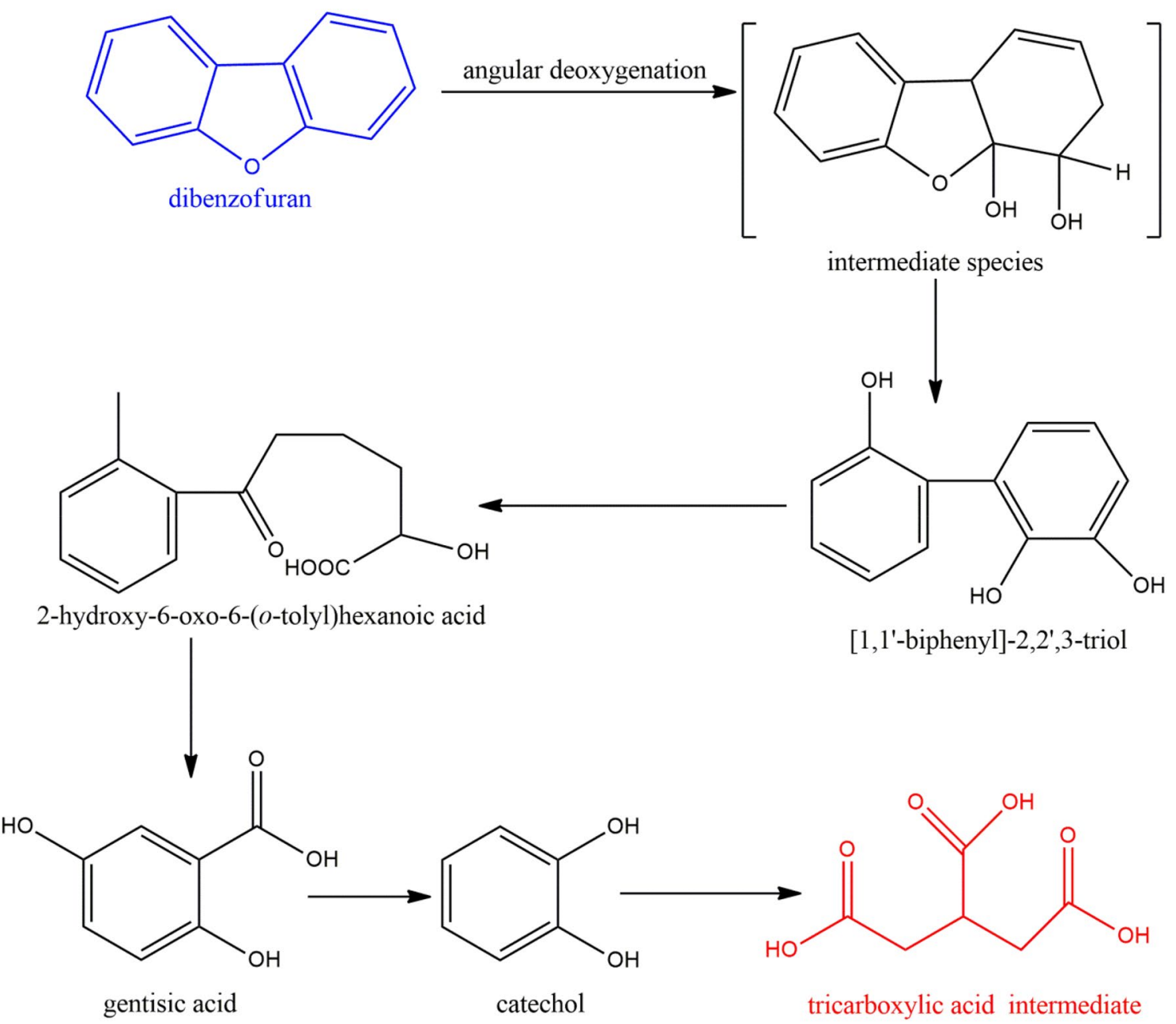

Scheme 4 Metabolic pathways for degradation of dibenzofuran by Pseudomonas sp. strain Modified from Jaiswal et al. [43]

of carbon, nitrogen and energy [78]. In addition to the scarce literature on these nitrogenated analogues of dioxins and furans, the modes of environmental distribution, pharmacokinetics and kinetics of their elimination are not well documented. A decade ago, however; detection of these toxins from industrial emissions in Germany points at industrial activities being a possible major source [29]. Burning of biomass and municipal waste incineration generate carbazole in abundance even though carbazole and benzocarbazoles remain the major $\mathrm{N}$-containing compounds in petroleum, crude oil and coal [78, 133].

A new category of pollutants also referred to as nitrogen-containing polycyclic aromatic hydrocarbons (N-PAHs) or nitrogen containing-polycyclic aromatic compounds (N-PACs), with $\mathrm{N}$ in the aromatic ring analogous to poly aromatic hydrocarbons (PAHs) are believed to form from the degradation of lignocellulosic materials and sewage sludge [99]. Research has demonstrated that these particular compounds; N-PAHs are individually toxic or in a mixture with PAHs are more toxic and with greater biological damage than their corresponding PAH analogues, with their toxicity increasing with increase in the number of aromatic rings [4].

Clearly, there has been significant interest in the toxicity studies of these compounds. Previous studies have shown that they have serious toxicological impacts on natural ecosystems and in humans because of their widespread nature in various environmental samples; lakes, seas and river sediments as well as in soil samples although in significantly varying quantities [73]. For instance, the concentrations of 3-chlorocarbazole and 3,6-dichlorocarbazole were found to vary with soil depth, with a higher concentrations being recorded in the top humic layer of the soil contour [74]. lodine containing versions of polyhalogenated carbazoles are rare in the environment and therefore generally uncommon in natural products and no known study has isolated iodinated carbazoles in the environment at least 


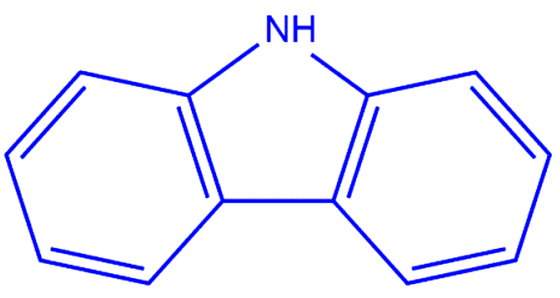

carbazole

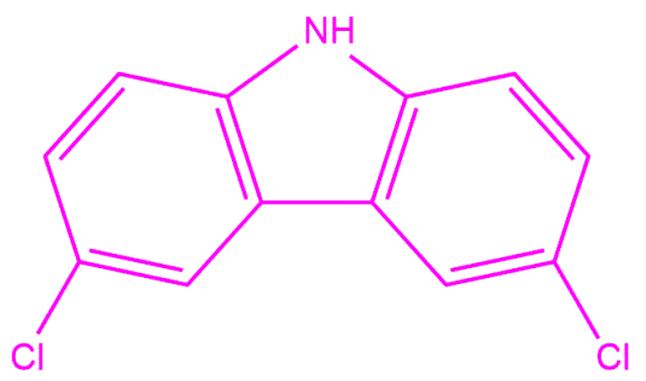

3,6-dichloro-9H-carbazole

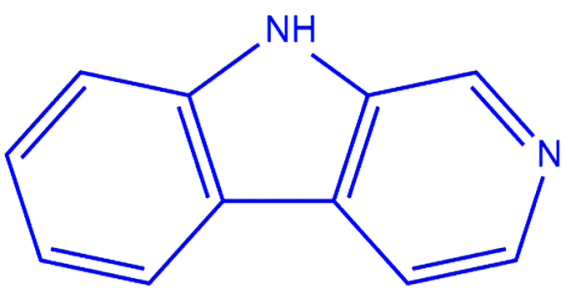

9H-pyrido[3,4-b]indole

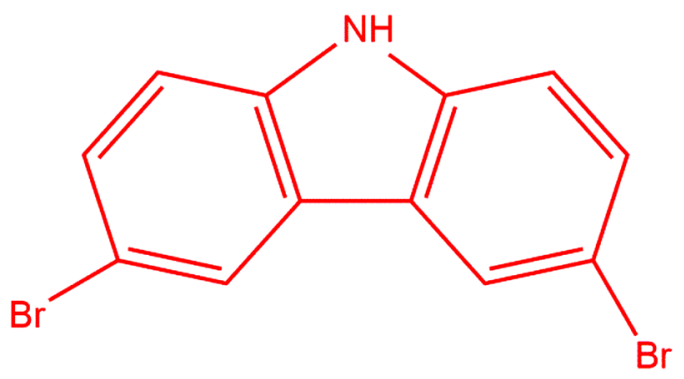

3,6-dibromo-9H-carbazole

Fig. 4 Nitrogenated analogues of dibenzofuran and dioxin-like compounds

to date [30]. Nonetheless, recent studies have found that iodinated carbazoles are more reactive than chlorinated or brominated carbazoles, and probably more lethal to the biological environment [91].

\section{Conclusions}

Persistent organic pollutants are a historical problem in the environmental ecosystem because of their long halflives which range from decades to centuries, and thus have far reaching implications in human and environmental health. Significant amount of monetary resources is applied to isolate these toxins from crude oil to prevent catalytic poisoning during oil refinery, and mopping up these unwanted chemicals from the natural environment; actions which result in negative economic impacts in general. Understanding how these toxins are formed in industries and combustion events, including municipal waste incineration will assist in developing the state-of-the-art destruction mechanisms by use of suppressants such as sulphur, microbial procedures and photo-dissociation. Organo chlorinated dioxins and furans are unintentional by-products of industrial combustion systems, and industrial processes ranging from cement production, pharmaceutical process, tanning and metallurgical activities. The acute toxicity of dioxins on public and environmental health impacts explained in this review should sensitize environmental authorities and medical personnel to demand for an environment free of toxicants especially in developing countries. On the other hand, polyhalogenated carbazoles (PHCZs), an emerging class of environmental toxins has been given extensive treatment in this review. They have increasingly been detected in the environment, and established to be bio-accumulative, although their potential transformation in the environment is basically unknown. Various measurement techniques have been proposed to detect and quantify the persistent organic pollutants discussed in this work and concluded that a combination of both physical methods such as a high resolution gas chromatograph hyphenated to a high resolution mass spectrometer and bioassay techniques such as the robust sensor technique is the best approach. The sensor technique is affordable, and provides real time results. This advancement in analytical measurement techniques has made biomonitoring and environmental assessment of dioxins and its associated analogues relatively easy for purposes of policy formulation and hazard regulations. The overall aim is to protect the environment and improve public health service delivery.

Acknowledgement The authors appreciate the support from the Directorate of Research and Extension of Egerton University.

Author's contribution SKK: Data curation; Validation: Writingoriginal draft: JKK: Conceptualization; Formal analysis; Supervision; Writing-review and editing: TKK: Data curation, Formal analysis; 
Supervision: Validation; Writing—review and editing: FIO: Methodology; Supervision: Visualization; Writing—review and editing.

\section{Compliance with ethical standards}

Conflict of interest The authors have no competing interests.

\section{References}

1. Altarawnehn M, Dlugogorskin BZ, Kennedy EM, Mackie JC (2009) Mechanisms for formation, chlorination, dechlorination and destruction of polychlorinated dibenzo-p-dioxins and dibenzofurans (PCDD/Fs). Prog Energy Combust Sci 35:245274. https://doi.org/10.1016/j.pecs.2008.12.001

2. Andersson JT, Achten C (2015) Time to say goodbye to the 16 EPA PAHs? Toward an up-to-date use of PACs for environmental purposes. Polycycl Aromat Compd 35:330-354. https://doi. org/10.1080/10406638.2014.991042

3. Ames J, Warner M, Mocarelli P, Brambilla P, Signorini S, Siracusa C, Huen K, Holland N, Eskenazi B (2018) AHR gene-dioxin interactions and birthweight in the Seveso Second Generation Health Study. Int J Epidemiol 47:1992-2004. https://doi. org/10.1093/ije/dyy165

4. Anyanwu IN, Semple KT (2015) Fate and behaviour of nitrogen-containing polycyclic aromatic hydrocarbons in soil. Environ Technol Innov 3:108-120. https://doi.org/10.1016/j. eti.2015.02.006

5. Arp HPH, Lundstendt $S$, Josefsson S, Cornelissen G, Enell A, Allard AS, Kleja DB (2014) Native oxy-PAHs, N-PACs, and PAHs in historically contaminated soils from Sweden, Belgium, and France: their soil-porewater partitioning behavior, bioaccumulation in Enchytraeus crypticus, and bioavailability. Environ Sci Technol 48:11187-11195. https://doi.org/10.1021/es5034469

6. Axegård $P$ (2019) The effect of the transition from elemental chlorine bleaching to chlorine dioxide bleaching in the pulp industry on the formation of PCDD/Fs. Chemosphere 236:124386. https://doi.org/10.1016/j.chemospher e. 2019.124386

7. Birnbaum LS, DeVito MJ (1995) Use of toxic equivalency factors for risk assessment for dioxins and related compounds. Toxicology 105:391-401. https://doi.org/10.1016/0300483X\%5b95\%5d03237-A

8. Carlson DB, Perdew GH (2002) A dynamic role for the Ah receptor in cell signaling? Insights from a diverse group of Ah receptor interacting proteins. J Biochem Mol Toxicol 16:317-325. https://doi.org/10.1002/jbt.10051

9. Chang YS (2008) Recent developments in microbial biotransformation and biodegradation of dioxins. J Mol Microbiol Biotechnol 15:152-171. https://doi.org/10.1159/000121327

10. Chen WY, Wu JH, Lin SC, Chang JE (2016) Bioremediation of polychlorinated- $p$-dioxins/dibenzofurans contaminated soil using simulated compost-amended landfill reactors under hypoxic conditions. J Hazard Mater 312:159-168. https://doi. org/10.1016/j.jhazmat.2016.03.060

11. Chobtang J, De Boer IJ, Hoogenboom RL, Haasnoot W, Kijlstra A, Meerburg BG (2011) The need and potential of biosensors to detect dioxins and dioxin-like polychlorinated biphenyls along the milk, eggs and meat food chain. Sensors 11:11692-11716. https://doi.org/10.3390/s111211692

12. Crosbyn DG, Wong AS (1977) Environmental degradation of 2 , 3, 7, 8-tetrachlorodibenzo-p-dioxin (TCDD). Science 195:13371338. https://doi.org/10.1126/science.841331
13. De Bergn MV, Peterson RE, Schrenk D (2000) Human risk assessment and TEFs. Food Addit Contam 17:347-358. https ://doi.org/10.1080/026520300283414

14. Denison M, Heath-Pagliuso S (1998) The Ah receptor: a regulator of the biochemical and toxicological actions of structurally diverse chemicals. Bull Environ Contam Toxicol 61:557-568. https://doi.org/10.1007/PL00002973

15. Denison MS, Nagy SR (2003) Activation of the aryl hydrocarbon receptor by structurally diverse exogenous and endogenous chemicals. Annu Rev Pharmacol Toxicol 43:309-334. https://doi.org/10.1146/annurev.pharmtox.43.100901.13582 8

16. Djien Liem A, Furst P, Rappe C (2000) Exposure of populations to dioxins and related compounds. Food Addit Contam 17:241259. https://doi.org/10.1080/026520300283324

17. Eichbaum K, Brinkmann M, Buchinger S, Reifferscheid G, Hecker M, Giesy JP, Engwall M, van Bavel B, Hollert H (2014) In vitro bioassays for detecting dioxin-like activity-application potentials and limits of detection, a review. Sci Total Environ 487:37-48. https://doi.org/10.1016/j.scitotenv.2014.03.057

18. Environmental Australia (1999) Incineration and dioxins: review of formation processes. Environmental and safety services for environment Australia. Canberra, Australia

19. Faboya OL, Sonibare OO, Liao Z, Ekundayo O, Tian Y (2015) Oil-source rock correlation and distributions of pyrrolic nitrogen compounds in oils From the Niger Delta, Nigeria. Pet Sci Technol 33:1253-1266. https://doi.org/10.1080/10916 466.2015.1050505

20. Faiad W, Hanano A, Kabakibi MM, Abbady AQ (2016) Immunodetection of dioxins using a recombinant protein of aryl hydrocarbon receptor (AhR) fused with sfGFP. BMC Biotechnol 16:51. https://doi.org/10.1186/s12896-016-0282-9

21. Fallarino F, Romani L, Puccetti P (2014) AhR: far more than an environmental sensor. Cell Cycle 13:2645-2646. https://doi. org/10.4161/15384101.2014.954219

22. Fan AM (2014) Chapter 64: biomarkers in toxicology, risk assessment, and environmental chemical regulations. In: Gupta RC (ed) Biomarkers in toxicology. Academic Press, Boston, pp 1057-1080. https://doi.org/10.1016/B978-0-12-40463 $0-6.00064-6$

23. Fang M, Guo J, Chen D, Li A, Hinton DE, Dong W (2016) Halogenated carbazoles induce cardiotoxicity in developing zebrafish (Danio rerio) embryos. Environ Toxicol Chem 35:2523-2529. https://doi.org/10.1002/etc.3416

24. Feeley M, Brouwer A (2000) Health risks to infants from exposure to PCBs, PCDDs and PCDFs. Food Addit Contam 17:325333. https://doi.org/10.1080/026520300283397

25. Fent K (2001) Fish cell lines as versatile tools in ecotoxicology: assessment of cytotoxicity, cytochrome P4501A induction potential and estrogenic activity of chemicals and environmental samples. Toxicol In Vitro 15:477-488. https://doi. org/10.1016/S0887-2333(01)00053-4

26. Fernandez-Gonzalez R, Yebra-Pimentel I, Martinez-Carballo E, Simal-Gandara J (2015) A critical review about human exposure to polychlorinated dibenzo- $p$-dioxins (PCDDs), polychlorinated dibenzofurans (PCDFs) and polychlorinated biphenyls (PCBs) through foods. Crit Rev Food Sci Nutr 55:1590-1617. https:// doi.org/10.1080/10408398.2012.710279

27. Fullana A, Conesa JA, Font R, Martín-Gullón I (2003) Pyrolysis of sewage sludge: nitrogenated compounds and pretreatment effects. J Anal Appl Pyrol 68:561-575. https://doi.org/10.1016/ S0165-2370(03)00052-4

28. Gavlasova P, Kuncova G, Kochankova L, Mackova M (2008) Whole cell biosensor for polychlorinated biphenyl analysis based on optical detection. Int Biodeterior Biodegrad 62:304312. https://doi.org/10.1016/j.ibiod.2008.01.015 
29. Gocht T, Klemm O, Grathwohl P (2007) Long-term atmospheric bulk deposition of polycyclic aromatic hydrocarbons (PAHs) in rural areas of Southern Germany. Atmos Environ 41:1315-1327. https://doi.org/10.1016/j.atmosenv.2006.09.036

30. Gribble GW (2009) Naturally occurring organohalogen compounds-a comprehensive update. Springer, New York

31. Gu YZ, Hogenesch JB, Bradfield CA (2000) The PAS superfamily: sensors of environmental and developmental signals. Annu Rev Pharmacol Toxicol 40:519-561. https://doi.org/10.1146/ annurev.pharmtox.40.1.519

32. Guo J, Li Z, Ranasinghe P, Bonina S, Hosseini S, Corcoran MB, Smalley C, Rockne KJ, Sturchio NC, Giesy JP (2017) Spatial and temporal trends of polyhalogenated carbazoles in sediments of upper Great Lakes: insights into their origin. Environ Sci Technol 51:89-97. https://doi.org/10.1021/acs.est.6b06128

33. Güzel B, Canli O, Dede Ş, Karademir A (2020) Assessment of $\mathrm{PCDD} / \mathrm{F}$ and dioxin-like $\mathrm{PCB}$ levels in environmental and food samples in the vicinity of IZAYDAS waste incinerator plant (WIP): from past to present. Environ Sci Pollut Res. https://doi. org/10.1007/s11356-020-07995-y

34. Hahn ME (2002) Aryl hydrocarbon receptors: diversity and evolution. Chem Biol Interact 141:131-160. https://doi. org/10.1016/S0009-2797(02)00070-4

35. Hahn ME (2002) Biomarkers and bioassays for detecting dioxinlike compounds in the marine environment. Sci Total Environ 289:49-69. https://doi.org/10.1016/S0048-9697(01)01016-6

36. Hajizadeh Y, Onwudili JA, Williams PT (2011) PCDD/F formation from oxy-PAH precursors in waste incinerator flyash. Chemosphere $85: 1672-1681$. https://doi.org/10.1016/j.chemospher e.2011.07.078

37. Hart JR (2004) Emissions of polychlorinated dibenzo-p-dioxins and dibenzofurans from catalytic and thermal oxidizers burning dilute chlorinated vapors. Chemosphere 54:1539-1547. https://doi.org/10.1016/j.chemosphere.2003.10.017

38. Heinzow B, Mohr S, Ostendorp G, Kerst M, Körner W (2007) $P C B$ and dioxin-like $P C B$ in indoor air of public buildings contaminated with different $P C B$ sources-deriving toxicity equivalent concentrations from standard PCB congeners. Chemosphere 67:1746-1753. https://doi.org/10.1016/j.chemospher e.2006.05.120

39. Hites RA (2011) Dioxins: an overview and history. Environ Sci Technol 45:16-20. https://doi.org/10.1021/es1013664

40. Hu J, Xiao X, Huang W, Chen D, Cai Y (2013) Spatial distribution of polychlorinated dibenzo-p-dioxins and dibenzo-furans (PCDDs/Fs) in dust, soil, sediment and health risk assessment from an intensive electronic waste recycling site in Southern China. Environ Sci Process Impacts 15:1889-1896. https://doi. org/10.1016/j.chemosphere.2019.124685

41. Huang $H$, Buekens $A$ (1995) On the mechanisms of dioxin formation in combustion processes. Chemosphere 31:4099-4117. https://doi.org/10.1016/0045-6535\%5b95\%5d80011-9

42. Jaffe D, Hafner W, Chand D, Westerling A, Spracklen D (2008) Interannual variations in PM2. 5 due to wildfires in the Western United States. Environ Sci Technol 42:2812-2818. https://doi. org/10.1021/es702755v

43. Jaiswal PK, Kohli S, Gopal M, Thakur IS (2011) Isolation and characterization of alkalotolerant Pseudomonas sp. strain ISTDF1 for degradation of dibenzofuran. J Ind Microbiol Biotechnol 38:503-511. https://doi.org/10.1007/s10295-010-0793-7

44. Jeon JR, Murugesan K, Baldrian P, Schmidt S, Chang YS (2016) Aerobic bacterial catabolism of persistent organic pollutants-potential impact of biotic and abiotic interaction. Curr Opin Biotechnol 38:71-78. https://doi.org/10.1016/j.copbi 0.2015 .12 .016

45. Jha AM, Bharti MK (2002) Mutagenic profiles of carbazole in the male germ cells of Swiss albino mice. Mutat Res, Fundam
Mol Mech Mutagen 500:97-101. https://doi.org/10.1016/ S0027-5107(01)00303-7

46. Kanan S, Samara F (2018) Dioxins and furans: a review from chemical and environmental perspectives. Trends Environ Anal Chem 17:1-13. https://doi.org/10.1016/j. teac.2017.12.001

47. Kawajiri K, Fujii-Kuriyama Y (2017) The aryl hydrocarbon receptor: a multifunctional chemical sensor for host defense and homeostatic maintenance. Exp Anim 66:75-89. https://doi. org/10.1538/expanim.16-0092

48. Kerger BD, Leung HW, Scott P, Paustenbach DJ, Needham LL, Patterson DG Jr, Gerthoux PM, Mocarelli P (2006) Age-and concentration-dependent elimination half-life of 2, 3, 7, 8-tetrachlorodibenzo- $p$-dioxin in Seveso children. Environ Health Perspect 114:1596-1602. https://doi.org/10.1289/ehp.8884

49. Kilbane JJ II (2006) Microbial biocatalyst developments to upgrade fossil fuels. Curr Opin Biotechnol 17:305-314. https ://doi.org/10.1016/j.copbio.2006.04.005

50. Konduri R, Altwicker E (1994) Analysis of time scales pertinent to dioxin/furan formation on fly ash surfaces in municipal solid waste incinerators. Chemosphere 28:23-45. https://doi. org/10.1021/es048771g

51. Kubota A, Iwata H, Tanabe S, Yoneda K, Tobata S (2005) Hepatic CYP1A induction by dioxin-like compounds, and congenerspecific metabolism and sequestration in wild common cormorants from Lake Biwa, Japan. Environ Sci Technol 39:3611-3619. https://doi.org/10.1021/es048771g

52. Kulkarni PS, Crespo JG, Afonso CA (2008) Dioxins sources and current remediation technologies-a review. Environ Int 34:139-153. https://doi.org/10.1016/j.envint.2007.07.009

53. Kurosawa S, Aizawa H, Park JW (2005) Quartz crystal microbalance immunosensor for highly sensitive 2,3,7,8-tetrachlorodibenzo- $p$-dioxin detection in fly ash from municipal solid waste incinerators. Analyst 130:1495-1501. https://doi. org/10.1039/B506151B

54. Kuzuhara S, Sato H, Kasai E, Nakamura T (2003) Influence of metallic chlorides on the formation of PCDD/Fs during lowtemperature oxidation of carbon. Environ Sci Technol 37:24312435. https://doi.org/10.1021/es034041h

55. La Merrill M, Emond C, Kim MJ, Antignac JP, Le Bizec B, Clément K, Birnbaum LS, Barouki R (2013) Toxicological function of adipose tissue: focus on persistent organic pollutants. Environ Health Perspect 121:162-169. https://doi.org/10.1289/ ehp. 1205485

56. Larentis A, Sampaio H, Carneiro C, Martins O, Alves T (2011) Evaluation of growth, carbazole biodegradation and anthranilic acid production by Pseudomonas stutzeri. Braz J Chem Eng 28:37-44. https://doi.org/10.1590/S0104-66322011000100005

57. Lavric ED, Konnov AA, De Ruyck J (2004) Dioxin levels in wood combustion-a review. Biomass Bioenergy 26:115-145. https ://doi.org/10.1016/S0961-9534(03)00104-1

58. Lee WJ, Shih SI, Chang CY, Lai YC, Wang LC, Chang-Chien GP (2008) Thermal treatment of polychlorinated dibenzo-p-dioxins and dibenzofurans from contaminated soils. J Hazard Mater 160:220-227. https://doi.org/10.1016/j.jhazmat.2008.02.113

59. Leung H, Kerger B, Paustenbach D, Ryan J, Masuda Y (2007) Concentration and age-dependent elimination kinetics of polychlorinated dibenzofurans in Yucheng and Yusho patients. Toxicol Ind Health 23:493-501. https://doi.org/10.1177/07482 33708089024

60. Lin X, Zhan M, Yan M, Dai A, Wu H, Li X, Chen T, Lu S, Yan J (2015) Suppression of dioxins in waste incinerator emissions by recirculating $\mathrm{SO}_{2}$. Chemosphere 133:75-81. https://doi. org/10.1016/j.chemosphere.2015.03.080

61. Liu X, Wang J, Wang X, Zhu T (2015) Simultaneous removal of PCDD/Fs and NOx from the flue gas of a municipal solid 
waste incinerator with a pilot plant. Chemosphere 133:90-96. https://doi.org/10.1016/j.chemosphere.2015.04.009

62. Lu S, Buekens A, Chen T, Lin X, Zhan M, Zhang M (2020) Dioxins and dioxin-like compounds. In: Nzihou A (ed) Handbook on characterization of biomass, biowaste and related by-products. Springer, Berlin, pp 1211-1265. https://doi. org/10.1007/978-3-030-35020-8_13

63. Lundstedt S, Haglund P, Öberg L (2003) Degradation and formation of polycyclic aromatic compounds during bioslurry treatment of an aged gasworks soil. Environ Toxicol Chem Int J 22:1413-1420. https://doi.org/10.1002/etc.5620220701

64. Luofu LIU (1998) Distribution and significance of carbazole compounds in palaeozoic oils from the Tazhong Uplift, Tarim. Acta Geol Sin English Edition 72:87-93. https://doi. org/10.1111/j.1755-6724.1998.tb00735.x

65. Ma Q (2012) Overview of AHR functional domains and the classical AHR signaling pathway: induction of drug metabolizing enzymes. The $\mathrm{AH}$ receptor in biology and toxicology; Pohjanvirta R, Ed, pp 35-45

66. Mascini M, Macagnano A, Monti D, del Carlo M, Paolesse $R$, Chen B, Warner P, D'Amico A, di Natale C, Compagnone D (2004) Piezoelectric sensors for dioxins: a biomimetic approach. Biosens Bioelectron 20:1203-1210. https://doi. org/10.1016/j.bios.2004.06.048

67. McKay G (2002) Dioxin characterisation, formation and minimisation during municipal solid waste (MSW) incineration. Chem Eng J 86:343-368. https://doi.org/10.1016/S1385 -8947(01)00228-5

68. Mendenhall EM, Williamson K, Reyon D, Joung JK, Bernstein BE (2013) Identification of promoter targets of enhancers by epigenetic knockdown using TAL DNA binding proteins. Epigenetics \& Chromatin 6:012. https://doi. org/10.1186/1756-8935-6-S1-012

69. Mitoma C, Uchi H, Tsukimori K, Yamada H, Akahane M, Imamura T, Utani A, Furue M (2015) Yusho and its latest findings-a review in studies conducted by the Yusho Group. Environ Int 82:41-48. https://doi.org/10.1016/j.envint.2015.05.004

70. Molen GWVd, Kooijman BA, Wittsiepe J, Schrey P, Flesch-Janys D, Slob W (2000) Estimation of dioxin and furan elimination rates with a pharmacokinetic model. J Expo Anal Environ Epidemiol 10:579-585. https://doi.org/10.1038/sj.jea.7500140

71. Mubeen I, Buekens A, Chen Z, Lu S, Yan J (2017) De novo formation of dioxins from milled model fly ash. Environ Sci Pollut Res 24:19031-19043. https://doi.org/10.1007/s1135 6-017-9528-x

72. Mumbo J, Henkelmann B, Abdelaziz A, Pfister G, Nguyen N, Schroll R, Munch JC, Schramm KW (2015) Persistence and dioxin-like toxicity of carbazole and chlorocarbazoles in soil. Environ Sci Pollut Res 22:1344-1356. https://doi.org/10.1007/ s11356-014-3608-y

73. Mumbo J, Lenoir D, Henkelmann B, Schramm KW (2013) Enzymatic synthesis of bromo-and chlorocarbazoles and elucidation of their structures by molecular modeling. Environ Sci Pollut Res 20:8996-9005. https://doi.org/10.1007/s1135 6-013-1823-6

74. Mumbo J, Pandelova M, Mertes F, Henkelmann B, Bussian BM, Schramm KW (2016) The fingerprints of dioxin-like bromocarbazoles and chlorocarbazoles in selected forest soils in Germany. Chemosphere 162:64-72. https://doi.org/10.1016/j. chemosphere.2016.07.056

75. Muñoz M, Gullett BK, Touati A, Font R (2012) Effect of 2,4-dichlorophenoxyacetic acid (2,4-D) on PCDD/F emissions from open burning of biomass. Environ Sci Technol 46:9308-9314. https ://doi.org/10.1021/es301954t

76. Nganai S, Lomnicki S (2017) Surface catalysed PCDD/F formation from precursors: high PCDF yield does not indicate de novo mechanism! Int J Environ Pollut 61:208-222. https://doi. org/10.1504/IJEP.2017.10008687

77. Nilsson CB, Håkansson H (2002) The retinoid signaling system-a target in dioxin toxicity. Crit Rev Toxicol 32:211-232. https://doi.org/10.1080/20024091064228

78. Nojiri H, Omori T (2007) Carbazole metabolism by pseudomonads. In: Ramos JL, Filloux A (eds) Pseudomonas. Springer, Dordrecht, pp 107-145. https://doi. org/10.1007/978-1-4020-6097-7_5

79. Northcross AL, Hammond SK, Canuz E, Smith KR (2012) Dioxin inhalation doses from wood combustion in indoor cookfires. Atmos Environ 49:415-418. https://doi.org/10.1016/j.atmos env.2011.11.054

80. Numata M, Yarita T, Aoyagi Y, Takatsu A (2003) Microwaveassisted steam distillation for simple determination of polychlorinated biphenyls and organochlorine pesticides in sediments. Anal Chem 75:1450-1457. https://doi.org/10.1021/ ac0262513

81. Okey AB (2007) An aryl hydrocarbon receptor odyssey to the shores of toxicology: the Deichmann lecture, international congress of toxicology-XI. Toxicol Sci 98:5-38. https://doi. org/10.1093/toxsci/kfm096

82. Okey AB, Franc MA, Moffat ID, Tijet N, Boutros PC, Korkalainen M, Tuomisto J, Pohjanvirta R (2005) Toxicological implications of polymorphisms in receptors for xenobiotic chemicals: the case of the aryl hydrocarbon receptor. Toxicol Appl Pharmacol 207:43-51. https://doi.org/10.1016/j.taap.2004.12.028

83. Ooi TC, Lu L (2011) Formation and mitigation of PCDD/Fs in iron ore sintering. Chemosphere 85:291-299. https://doi. org/10.1016/j.chemosphere.2011.08.020

84. Palanisami N, Chung SJ, Moon IS (2015) Cerium(IV)-mediated electrochemical oxidation process for removal of polychlorinated dibenzo-p-dioxins and dibenzofurans. J Ind Eng Chem 28:28-31. https://doi.org/10.1016/j.jiec.2014.10.047

85. Pan Y, Yang L, Zhou J, Liu J, Qian G, Ohtsuka N, Motegi M, Oh K, Hosono S (2013) Characteristics of dioxins content in fly ash from municipal solid waste incinerators in China. Chemosphere 92:765-771. https://doi.org/10.1016/j.chemospher e.2013.04.003

86. Parette $R$, McCrindle R, McMahon KS, Pena-Abaurrea M, Reiner E, Chittim B, Riddell N, Voss G, Dorman FL, Pearson WN (2015) Halogenated indigo dyes: a likely source of 1, 3, 6, 8-tetrabromocarbazole and some other halogenated carbazoles in the environment. Chemosphere 127:18-26. https://doi. org/10.1016/j.chemosphere.2015.01.001

87. Perez G, Mascini M, Lanzone V, Sergi M, Del Carlo M, Esposito M, Compagnone D (2013) Peptides trapping dioxins: a docking-based inverse screening approach. J Chem. https://doi. org/10.1155/2013/491827

88. Petronijevic R, Radicevic T, Jankovic V (2015) Methods for determination of dioxins and dioxin-like compounds: a brief review of recent advances. Procedia Food Sci 5:227-230. https://doi. org/10.1016/j.profoo.2015.09.036

89. Pham PL (2019) Assessment of soil quality and dioxin contamination at Bien Hoa Airbase, Vietnam. http://urn.fi/ URN:NBN:fi:amk-2019060214070. Accessed 27 Apr 2020

90. Poberezhnaya TM (2012) Endogenous sources of dioxin emissions in areas of tectonomagmatic activation using the example of the Sakhalin-Kuril region. Russ J Pac Geol 6:433-435. https://doi.org/10.1134/S181971401206005X

91. Przypis L, Walczak KZ (2019) Copper(II)-catalyzed iodinations of carbazoles: access to functionalized carbazoles. J Org Chem 84:2287-2296. https://doi.org/10.1021/acs.joc.8b02821

92. Riddell N, Jin UH, Safe S, Cheng Y, Chittim B, Konstantinov $A$, Parette $R$, Pena-Abaurrea $M$, Reiner EJ, Poirier $D$ (2015) Characterization and biological potency of mono-to 
tetra-halogenated carbazoles. Environ Sci Technol 49:1065810666. https://doi.org/10.1021/acs.est.5b02751

93. Rose M (2014) Environmental contaminants: dioxins, furans, and dioxin-like polychlorinated biphenyls. Encycl Food Saf. https://doi.org/10.1016/b978-0-12-378612-8.00197-9

94. Saarikoski S, Sillanpää M, Sofiev M, Timonen H, Saarnio K, Teinilä K, Karppinen A, Kukkonen J, Hillamo R (2007) Chemical composition of aerosols during a major biomass burning episode over northern Europe in spring 2006: experimental and modelling assessments. Atmos Environ 41:3577-3589. https://doi. org/10.1016/j.atmosenv.2006.12.053

95. Safe S, Hutzinger O, Hill TA (2012) Polychlorinated dibenzop-dioxins and-furans (PCDDs/PCDFs): Sources and environmental impact, epidemiology, mechanisms of action, health risks. Springer, New York

96. Safe SH (1998) Development validation and problems with the toxic equivalency factor approach for risk assessment of dioxins and related compounds. J Anim Sci 76:134-141. https ://doi.org/10.2527/1998.761134x

97. Saibu S, Adebusoye SA, Oyetibo GO (2020) Aerobic bacterial transformation and biodegradation of dioxins: a review. Bioresour Bioprocess 7:1-21. https://doi.org/10.1186/s4064 3-020-0294-0

98. Saidur R, Abdelaziz E, Demirbas A, Hossain M, Mekhilef S (2011) A review on biomass as a fuel for boilers. Renew Sustain Energy Rev 15:2262-2289. https://doi.org/10.1016/j.rser.2011.02.015

99. Salam LB, llori MO, Amund OO (2017) Properties, environmental fate and biodegradation of carbazole. 3 Biotech 7:111. https ://doi.org/10.1007/s13205-017-0743-4

100. Samara F, Gullett BK, Harrison RO, Chu A, Clark GC (2009) Determination of relative assay response factors for toxic chlorinated and brominated dioxins/furans using an enzyme immunoassay (EIA) and a chemically-activated luciferase gene expression cell bioassay (CALUX). Environ Int 35:588-593. https://doi. org/10.1016/j.envint.2008.11.003

101. Schmidt AW, Reddy KR, Knölker HJ (2012) Occurrence, biogenesis, and synthesis of biologically active carbazole alkaloids. Chem Rev 112:3193-3328. https://doi.org/10.1021/cr200447s

102. Schramm KW, Klimm C, Hofmaier A, Kettrup A (2001) Comparison of dioxin-like-response in vitro and chemical analysis of emissions and materials. Chemosphere 42:551-557. https:// doi.org/10.1016/S0045-6535(00)00227-7

103. Shih SI, Lee WJ, Lin LF, Huang JY, Su JW, Chang-Chien GP (2008) Significance of biomass open burning on the levels of polychlorinated dibenzo- $p$-dioxins and dibenzofurans in the ambient air. J Hazard Mater 153:276-284. https://doi.org/10.1016/j. jhazmat.2007.08.048

104. Sorg O, Zennegg M, Schmid P, Fedosyuk R, Valikhnovskyi R, Gaide O, Kniazevych V, Saurat JH (2009) 2, 3, 7, 8-tetrachlorodibenzo- $p$-dioxin (TCDD) poisoning in Victor Yushchenko: identification and measurement of TCDD metabolites. The Lancet 374:1179-1185. https://doi.org/10.1016/S0140-6736(09)60912 $-0$

105. Stanmore $B$ (2004) The formation of dioxins in combustion systems. Combust Flame 136:398-427. https://doi.org/10.1016/j. combustflame.2003.11.004

106. Stanmore BR (2002) Modeling the formation of PCDD/F in solid waste incinerators. Chemosphere 47:565-573. https:// doi.org/10.1016/S0045-6535(02)00005-X

107. Stieglitz $L$ (1998) Selected topics on the de novo synthesis of PCDD/PCDF on fly ash. Environ Eng Sci 15:5-18. https://doi. org/10.1089/ees.1998.15.5

108. Stieglitz L, Eichberger M, Schleihauf J, Beck J, Zwick G, Will R (1993) The oxidative degradation of carbon and its role in the de-novo-synthesis of organohalogen compounds in fly ash.
Chemosphere 27:343-350. https://doi.org/10.1016/00456535\%5b93\%5d $90311-R$

109. Suzuki K, Kasai E, Aono T, Yamazaki H, Kawamoto K (2004) De novo formation characteristics of dioxins in the dry zone of an iron ore sintering bed. Chemosphere 54:97-104. https:// doi.org/10.1016/S0045-6535(03)00708-2

110. Tian W, Xie HQ, Fu H, Pei X, Zhao B (2012) Immunoanalysis methods for the detection of dioxins and related chemicals. Sensors 12:16710-16731. https://doi.org/10.3390/s121216710

111. Tuomisto J (2019) Dioxins and dioxin-like compounds: toxicity in humans and animals, sources, and behaviour in the environment. WikiJ Med 6:8. https://doi.org/10.15347/wjm/2019.008

112. Tuomisto J, Vartiainen T, Tuomisto JT (2011) Synopsis on dioxins and PCBs. http://urn.fi/URN:NBN:fi-fe201205085413. Accessed 27 Apr 2020

113. Tuppurainen K, Asikainen A, Ruokojärvi P, Ruuskanen J (2003) Perspectives on the formation of polychlorinated dibenzo- $p$-dioxins and dibenzofurans during municipal solid waste (MSW) incineration and other combustion processes. Acc Chem Res 36:652-658. https://doi.org/10.1021/ar020104+

114. Tuppurainen K, Halonen I, Ruokojärvi P, Tarhanen J, Ruuskanen J (1998) Formation of PCDDs and PCDFs in municipal waste incineration and its inhibition mechanisms: a review. Chemosphere 36:1493-1511. https://doi.org/10.1016/S0045 $-6535 \% 5 b 97 \% 5 d 10048-0$

115. van den Berg $M$, Birnbaum $L$, Denison $M$, De Vito $M$, Farland $W$, Feeley M, Fiedler H, Hakansson H, Hanberg A, Haws L (2006a) Human and mammalian toxic equivalency factors for dioxins and dioxin-like compounds: the WHO 2005 re-evaluation. In: Organohalogen compounds (Proceedings of Dioxin 2006: 26th international symposium on halogenated environmental organic pollutants and POPs.). https://doi.org/10.1093/toxsci/ kfl055

116. van den Berg $M$, Birnbaum LS, Denison $M$, De Vito $M$, Farland W, Feeley M, Fiedler H, Hakansson H, Hanberg A, Haws L (2006) The 2005 World Health Organization reevaluation of human and mammalian toxic equivalency factors for dioxins and dioxin-like compounds. Toxicol Sci 93:223-241. https://doi. org/10.1093/toxsci/kfl055

117. van der Molen G, Kooijman S, Slob W (1996) A generic toxicokinetic model for persistent lipophilic compounds in humans: an application to TCDD. Toxicol Sci 31:83-94. https://doi. org/10.1093/toxsci/31.1.83

118. van Ede Kl, van Duursen MBM, van den Berg M (2016) Evaluation of relative effect potencies (REPs) for dioxin-like compounds to derive systemic or human-specific TEFs to improve human risk assessment. Arch Toxicol 90:1293-1305. https://doi. org/10.1007/s00204-016-1724-9

119. Vartiainen T, Jaakkola J, Saarikoski S, Tuomisto J (1998) Birth weight and sex of children and the correlation to the body burden of PCDDs/PCDFs and PCBs of the mother. Environ Health Perspect 106:61-66. https://doi.org/10.1289/ehp.9810661

120. Velusamy V, Arshak K, Korostynska O, Oliwa K, Adley C (2010) An overview of foodborne pathogen detection: in the perspective of biosensors. Biotechnol Adv 28:232-254. https:// doi.org/10.1016/j.biotechadv.2009.12.004

121. Virtanen $H$, Koskenniemi J, Sundqvist $E$, Main $K$, Kiviranta $\mathrm{H}$, Tuomisto J, Tuomisto J, Viluksela M, Vartiainen T, Skakkebaek N (2012) Associations between congenital cryptorchidism in newborn boys and levels of dioxins and PCBs in placenta. Int J Androl 35:283-293. https://doi.org/10.111 1/j.1365-2605.2011.01233.x

122. Wang SJ, He PJ, Lu WT, Shao LM, Zhang H (2016) Amino compounds as inhibitors of de novo synthesis of chlorobenzenes. Sci Rep 6:23197. https://doi.org/10.1038/srep23197 
123. Warenik-Bany M, Strucinski P, Piskorska-Pliszczynska J (2016) Dioxins and PCBs in game animals: interspecies comparison and related consumer exposure. Environ Int 89:21-29. https:// doi.org/10.1016/j.envint.2016.01.007

124. Watanabe MX, Kunisue $T$, Ueda N, Nose $M$, Tanabe $S$, Iwata $\mathrm{H}$ (2013) Toxicokinetics of dioxins and other organochlorine compounds in Japanese people: association with hepatic CYP1A2 expression levels. Environ Int 53:53-61. https://doi. org/10.1016/j.envint.2012.12.008

125. Weber R, Gaus C, Tysklind M, Johnston P, Forter M, Hollert $H$, Heinisch E, Holoubek I, Lloyd-Smith M, Masunaga S (2008) Dioxin-and POP-contaminated sites-contemporary and future relevance and challenges. Environ Sci Pollut Res 15:363. https://doi.org/10.1007/s11356-008-0024-1

126. Weber R, Tysklind M, Gaus C (2008) Dioxin-contemporary and future challenges of historical legacies. Environ Sci Pollut Res Int 15:96. https://doi.org/10.1065/espr2008.01.473

127. Weber $R$, lino $F$, Imagawa $T$, Takeuchi $M$, Sakurai $T$, Sadakata $M$ (2001) Formation of PCDF, PCDD, PCB, and PCN in de novo synthesis from PAH: mechanistic aspects and correlation to fluidized bed incinerators. Chemosphere 44:1429-1438. https ://doi.org/10.1016/S0045-6535(00)00508-7

128. Weidemann E, Buss W, Edo M, Mašek $O$, Jansson S (2018) Influence of pyrolysis temperature and production unit on formation of selected PAHs, oxy-PAHs, N-PACs, PCDDs, and PCDFs in biochar-a screening study. Environ Sci Pollut Res 25:39333940. https://doi.org/10.1007/s11356-017-0612-z

129. White SS, Birnbaum LS (2009) An overview of the effects of dioxins and dioxin-like compounds on vertebrates, as documented in human and ecological epidemiology. J Environ Sci Health Part C 27:197-211. https://doi.org/10.1080/1059050090 3310047
130. Yang J, Yan M, Li X, Lu S, Chen T, Yan J, Olie K, Buekens A (2015) Formation of dioxins on $\mathrm{NiO}$ and $\mathrm{NiCl}_{2}$ at different oxygen concentrations. Chemosphere 133:97-102. https://doi. org/10.1016/j.chemosphere.2015.03.077

131. Zhan MX, Pan S, Deviatkin I, Chen T, Li XD (2018) Thermal reaction characteristics of dioxins on cement kiln dust. RSC Adv 8:3582-3591. https://doi.org/10.1039/C7RA09220B

132. Zhang J, Jiang Y, Zhou J, Wu B, Liang Y, Peng Z, Fang D, Liu B, Huang $\mathrm{H}, \mathrm{He} C$ (2010) Elevated body burdens of PBDEs, dioxins, and $\mathrm{PCBs}$ on thyroid hormone homeostasis at an electronic waste recycling site in China. Environ Sci Technol 44:39563962. https://doi.org/10.1021/es902883a

133. Zhang L, Wang Y, Li MW, Yin QZ, Zhang W (2019) Relative sorption coefficient: key to tracing petroleum migration and other subsurface fluids. Sci Rep 9:16845. https://doi.org/10.1038/ s41598-019-52259-6

134. Zhang M, Buekens A (2016) De novo synthesis of dioxins: a review. Int J Environ Pollut 60:63-110. https://doi.org/10.1504/ IJEP.2016.082115

135. Zhang M, Buekens A, Li X (2017) Open burning as a source of dioxins. Crit Rev Environ Sci Technol 47:543-620. https://doi. org/10.1080/10643389.2017.1320154

136. Zhang T, Huang J, Deng S, Yu G (2011) Influence of pesticides contamination on the emission of PCDD/PCDF to the land from open burning of corn straws. Environ Pollut 159:1744-1748. https://doi.org/10.1016/j.envpol.2011.01.042

Publisher's Note Springer Nature remains neutral with regard to jurisdictional claims in published maps and institutional affiliations. 